\title{
MAGMATISMO ÁCIDO-BÁSICO NA ILHA DO ARVOREDO - SC
}

\author{
EDISON RAMOS TOMAZZOLIํㅛ \& EVANDRO FERNANDES DE LIMA ${ }^{2}$
}

\begin{abstract}
The rocks that constitute the Arvoredo Island are alkaline granites (Arvoredo Granite) that are cut by basaltic andesite dykes with variable thickness, striking $\mathrm{N} 10^{\circ}-20^{\circ} \mathrm{E}$. This dykes belongs to Florianópolis Dyke Swarm (Cretaceous age, gotten by $\mathrm{Ar}^{40} / \mathrm{Ar}^{39}$ data in previous paper - Tomazzoli et al., 2005) and are associated to rhyodacites and dacites that can occur as simple dykes, composite dykes or as hypabissal bodies of irregular geometry. The composite dykes are constituted by rhyodacite in the center with borders of basaltic andesite. Composite dykes and rounded enclaves of basaltic andesite in rhyodacite are features that indicate magma mingling process. The basaltic andesites and rhyodacite are high-K tholeiitic rocks with high Ti, $\mathrm{P}$ and uncompatible trace element contents. Geochemical modeling shows that rhyodacites can be derived from basaltic andesites by fractional crystalization of $61 \%$ of solids, represented by andesine (45.1\%), edenite (16.5\%), augite (18.7\%) magnetite $(9.8 \%)$ and ilmenite $(6.8 \%)$. The magma mixing/mingling process could have occured after the fractional crystallization. The geochemistry of rhyolite dykes and aplite veins differ from that of the tholeiitic rhyodacites/dacites and is similar to Arvoredo Granite.
\end{abstract}

Keywords: Arvoredo Island, Florianópolis Dyke Swarm, petrology, tholeiites

Resumo A Ilha do Arvoredo é constituída dominantemente por rochas graníticas alcalinas (Granito Arvoredo), secionadas por enxame de diques de andesito basáltico, com espessuras variadas e direção predominante $\mathrm{N} 10^{\circ}$ $20^{\circ} \mathrm{E}$. Esses diques são integrantes do Enxame de Diques Florianópolis, tendo em vista que determinações isotópicas ${ }^{40} \mathrm{Ar} /{ }^{39} \mathrm{Ar}$ indicaram idades cretáceas (Tomazzoli et al., 2005). Esses estão associados riodacitos e dacitos, que podem formar diques simples ou corpos hipabissais de geometria não bem definida, ou ainda diques compostos, com bordas de andesito basáltico e centro de riodacito. Além das feições de diques compostos, enclaves e microenclaves arredondados de andesito basáltico em riodadacito, indicam um processo de mistura entre os magmas formadores desses dois litotipos. Tanto os andesitos basálticos como os riodacitos têm afinidades toleíticas de alto $\mathrm{K}$, com grande enriquecimento em Ti, $\mathrm{P}$ e elementos-traço incompatíveis. Modelamento geoquímico mostrou que os riodacitos podem ter sido derivados dos andesitos basálticos por $61 \%$ de cristalização fracionada dos minerais andesina $(45,1 \%)$, edenita $(16,5 \%)$, augita $(18,7 \%)$, magnetita $(9,8 \%)$ e ilmenita $(6,8 \%)$. A geometria dos diques compostos indica que a mistura magmática, entre os termos riodacíticos e andesíticos basálticos, teria operado após o fracionamento. Diques de riolito e veios aplíticos são geoquimicamente diferenciados dos riodacitos toleíticos e mostram-se correlacionáveis ao Granito Arvoredo.

Palavras chave: Ilha do Arvoredo, Enxame de Diques Florianópois, petrologia, toleítos

INTRODUÇÃO A Ilha do Arvoredo, com área de aproximadamente $3,5 \mathrm{Km}^{2}$ de área, situa-se a norte da Ilha de Santa Catarina (Fig. 1A) e integra a Reserva Biológica Marinha do Arvoredo, administrada pelo IBAMA. O relevo é escarpado, com altitude máxima de $270 \mathrm{~m}$ e encostras íngremes, recobertas por vegetação florestal. Nos costões, observa-se excelentes exposições de rocha, que prolongam-se de forma contínua por grandes extensões em todo o entorno da ilha. Essas condições facilitam a visualização e caracterização dos litotipos, o que levou o trabalho a focalizar principalmente essas áreas.

\section{CONTEXTO GEOLÓGICO E CARACTERIZACÃO PE-} TROGRÁFICA DOS LITOTIPOS DOMINANTES GeOlogicamente, a Ilha do Arvoredo é constituída dominantemente por granito, diques de riolito, veios de aplito, diques de andesito basáltico, diques e corpos hipabissais de riodacito-dacito, diques compostos, brechas, cataclasitos e milonitos. Em algumas áreas observa-se depósitos quaternários, representados principalmente por areias de rampas dunárias.

O granito tem uma tonalidade rosada, granulação grossa e contém, freqüentemente, enclaves de formas, composições e dimensões variadas. Exibe textura eqüigranular hipidiomórfica, tendo como minerais essenciais feldspato alcalino, plagioclásio e quartzo; como varietais, hornblenda, biotita, óxidos de Fe-Ti, titanita e apatita; como secundários clorita, epidoto e sericita. A rocha pode ser classificada como sienogranito, com base em estimativas modais. Mostra características petrográficas e afinidade geoquímica, que permitem correlacioná-la ao aos granitóides alcalinos da Suíte Intrusiva Pedras Grandes, de idade neoproterozóica, descritos em Zanini et al.(1997). Nesse trabalho será tratada sob o nome de Granito Arvoredo. Enclaves no granito são normalmente arredondados, com dimensões centimétricas e composição que varia de básica até ácida.

Os riolitos ocorrem em diques com até 3 metros de espessura. São porfiríticos, com fenocristais rosados de K-fedspato e de quartzo sobre matriz afanítica de cor rosa, constituída por quartzo e por intercrescimentos micrográficos desse mineral com K-feldspato. Anfibólio verde, biotita, e óxidos de Fe-Ti, são os minerais varietais e acessórios mais freqüentes, associados a epidoto e clorita secundários.

Corpos de riodacito-dacito e de andesito basáltico ocorrem como intrusões, geralmente sob a forma de diques, cortando o Granito Arvoredo (Fig. 1B). Datações ${ }^{40} \mathrm{Ar} /{ }^{39} \mathrm{Ar}$ efetuadas nessas rochas no norte da Ilha do Arvoredo (Tomazzoli et al. 2005) indicaram idades de $135,0 \pm 1,1$ e $137,3 \pm 1,3$ Ma que permitem correlacioná-las ao Enxame de Diques Florianópolis, também

\footnotetext{
1 - Departamento de Geociências - Universidade Federal de Santa Catarina - UFSC, Campus Trindade, CEP 88.037-000, Florianópolis, SC-e-mail: edison@cfh.ufsc.br 2 - Curso de Pós-Graduação em Geociências - Universidade Federal do Rio Grande do Sul - UFRGS - Av. Bento Gonçalves, 9500 - Campus do Vale, 91501 -970, Porto Alegre, RS-e-mail: evandro.lima@ufrgs.br
} 


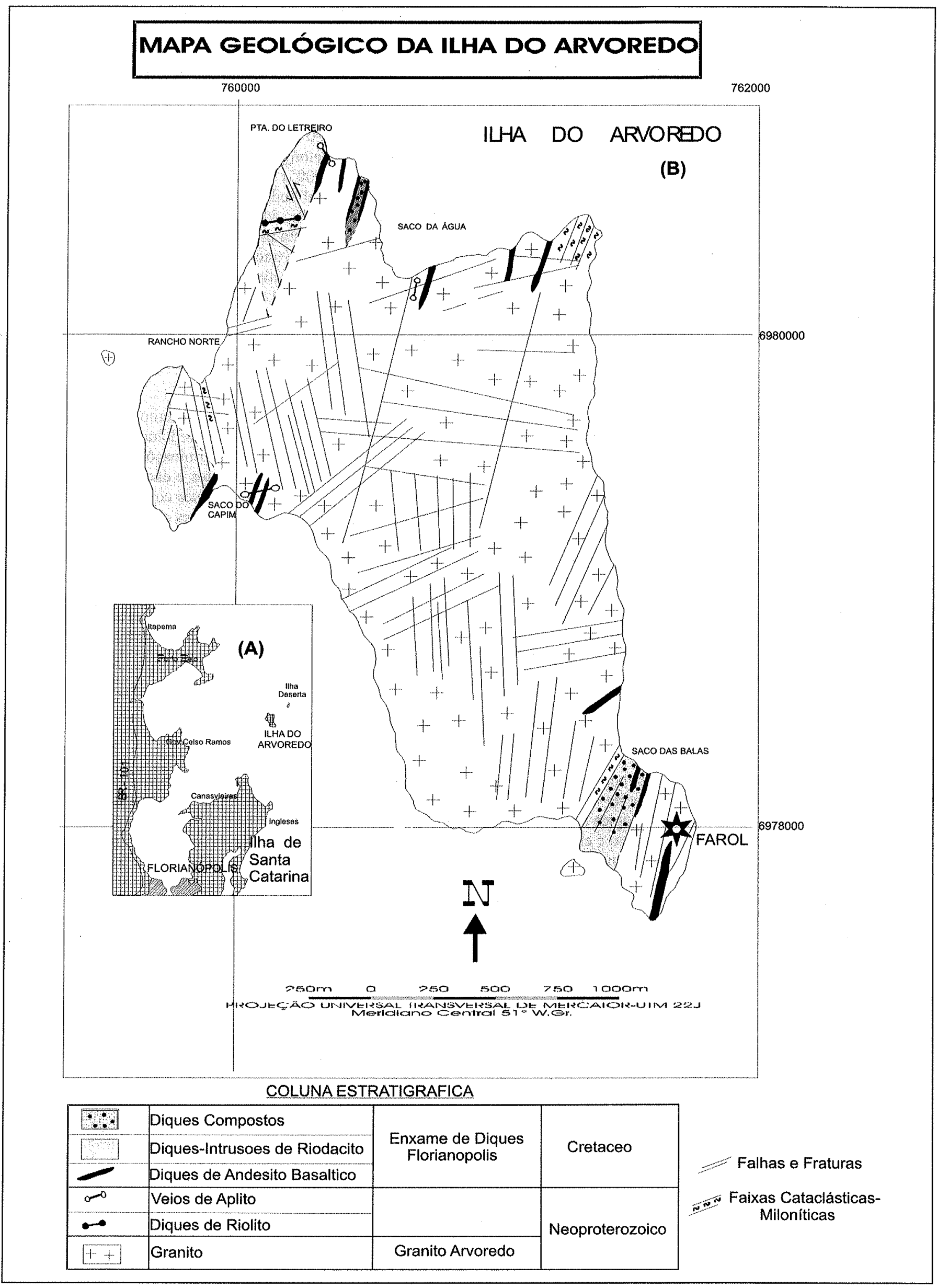

Figura I - (a) Mapa de localização. (b) Mapa geológico da Ilha do Arvoredo. 
de idade cretácea, datado por Raposo et al. (1998), que ocorre mais a sul, na Ilha de Santa Catarina (Fig. 1A).

Riodacitos-dacitos, exibem, freqüentemente, geometria de diques, embora, por vezes, as intrusões apresentem formas mais irregulares. O riodacito grada a dacito e, por vezes, contém enclaves básicos. Apresentam textura porfirítica, com fenocristais de quartzo e plagioclásio. Fazem contato com o granito por falhas ou fraturas sub verticais de direção $\mathrm{N} 10^{\circ}-20^{\circ} \mathrm{E}$.

Riodacitos, classificados com base em estimativas modais, exibem cor cinza mais claro, sendo comum a presença de mirmerquitos e intercrescimentos microgranofíricos na matriz. Mineralogicamente são constituídos por quartzo, plagioclásio $\left(\mathrm{An}_{12-45}\right)$, freqüentemente zonado com núcleo mais cálcico, $\mathrm{K}$ feldspato $\left(\mathrm{Or}_{40-42} \mathrm{Ab}_{60-58}\right)$, sempre subordinado ao plagioclásio, pigeonita $\left(\mathrm{Wo}_{8} \mathrm{En}_{50} \mathrm{Fs}_{42}\right.$ ) zonada com bordas de augita $\left(\mathrm{WO}_{37}\right.$ $E_{32} \mathrm{Fs}_{31}$ ) ou sem zonação. Os piroxênios estão substituídos total ou parcialmente por anfibólios. Magnetita, zircão e apatita são os minerais acessórios mais freqüentes.

Os dacitos, classificados em base química e em estimativas modais, são textural e mineralogicamente semelhantes aos riodacitos. Mineralogicamente apresentam quartzo, plagioclásio zonado, com núcleo de labradorita $\left(\mathrm{An}_{60}\right)$ e bordas de oligoclásio $\left(\mathrm{An}_{25}\right)$ Quando pófiros exibem fenocristais de labradorita zonada $\left(\mathrm{An}_{54-63}\right)$, com núcleo mais cálcico. Augita $\left(\mathrm{Wo}_{35-37} \mathrm{En}_{44-}\right.$ ${ }_{40} \mathrm{Fs}_{21-23}$ ), mostra-se parcial ou completamente substituída por actinolita ou $\mathrm{Mg}$ hornblenda. Magnetita, ilmenita e apatita são os minerais acessórios mais comuns.

Microenclaves de composição intermediária a básica nos dacitos/riodacitos possuem, geralmente, dimensões entre $6 \mathrm{e}$ $8 \mathrm{~mm}$, formas arredondadas e textura intergranular de granulação bem mais fina que a do dacito/riodacito encaixante.

Diques compostos foram observados no norte e no sudeste da Ilha do Arvoredo (Figura l). Costumam ser interpretados como injeções múltiplas de magmas contrastantes na mesma fissura (p. ex.: Taylor et al., 1980;. Bitencourt et al., 1989 e Bitencourt, 1996). O do norte possui espessura de aproximadamente 40 metros e direção N10 E. Sua porção central do dique é constituída riodacito, cor cinza claro, exibindo, ocasionalmente, microenclaves de composição básico-intermediária. Ambas as bordas, em contato com o granito, são constituídas por andesitos basálticos de cor escura. O dique composto do sudeste da Ilha do Arvoredo possui cerca de 80 metros de espessura e somente sua borda leste é constituída por andesito basáltico.

Diques de andesito basáltico, apresentam direção preferencial $\mathrm{N} 10^{\circ}-20^{\circ} \mathrm{E}$ e formam um grande enxame na Ilha do Arvoredo. Possuem espessuras variáveis, podendo atingir 60 metros.

Foram classificados com base em critérios litoquímicos (diagrama TAS), apesar de plotarem no campo dos andesitos quando classificados por estimativas modais dos minerais constitutivos da rocha (diagrama QAFP). São rochas de coloração escura, textura subofitica, ou, mais freqüentemente, textura intergranular fina, contendo grãos zonados de andesina/labradorita $\left(\mathrm{An}_{46-}\right.$ $\left.{ }_{55}\right)$ com bordas de andesina menos cálcica, augita $\left(\mathrm{WO}_{30-39} \mathrm{En}_{36-44}\right.$ $\mathrm{Fs}_{17-34}$ ), parcial ou totalmente substituída por actinolita, $\mathrm{Mg}$ ou Fe hornblenda. Muitas vezes o anfibólio apresenta-se parcialmente substituído por clorita. Óxidos de Fe-Ti exibem, freqüentemente, lamelas de intercrescimento (oxi-exolução); quartzo, titanita e apatita aparecem em pequenas proporções. Algumas amostras apresentam microenclaves de composição básica arredondados com 2 a $3 \mathrm{~mm}$ de diâmetro (Figs. 2A e 2B).

QUÍMICA MINERAL Análises da química mineral foram obtidas no Laboratório de Microssonda Eletrônica do Centro de Estudos em Petrologia e Geoquímica - IG-UFRGS. Utilizou-se o equipamento CAMECA SX50 equipada com quatro espectrômetros (WDS-wavelenght dispersive spectrometer). As análises foram realizadas com tensão de aceleração do feixe de $15 \mathrm{kV}$ e sob as seguintes condições: a) Piroxênio - corrente de feixe $=10 \mathrm{nA}$; diâmetro do feixe $=5 \mu \mathrm{m}$; b) Felspato - corrente de feixe $=10 \mathrm{nA}$; diâmetro do feixe $=1 \mu \mathrm{m}$; c) Anfibólio - corrente de feixe $=10 \mathrm{nA}$; diâmetro do feixe $=5 \mu \mathrm{m}$; d) Magnetita - corrente de feixe $=25 \mathrm{nA}$; diâmetro do feixe $=1 \mu \mathrm{m}$; e) Ilmenita - corrente de feixe $=25 \mathrm{nA}$; diâmetro do feixe $=1 \mu \mathrm{m}$.

Feldspatos $\mathrm{Na}$ Tabela $\mathrm{l}$ estão listadas amostras representativas de um total de 89 análises.

Os plagioclásios de andesitos basálticos de dique (Fig. 3a) apresentam zonações, com núcleos de labradorita $\left(\mathrm{An}_{50.57}\right)$ e bordas de andesina $\left(\mathrm{An}_{31-41}\right)$. Eventualmente as bordas podem ser ainda menos cálcicas, constituídas por oligoclásio (grão 2
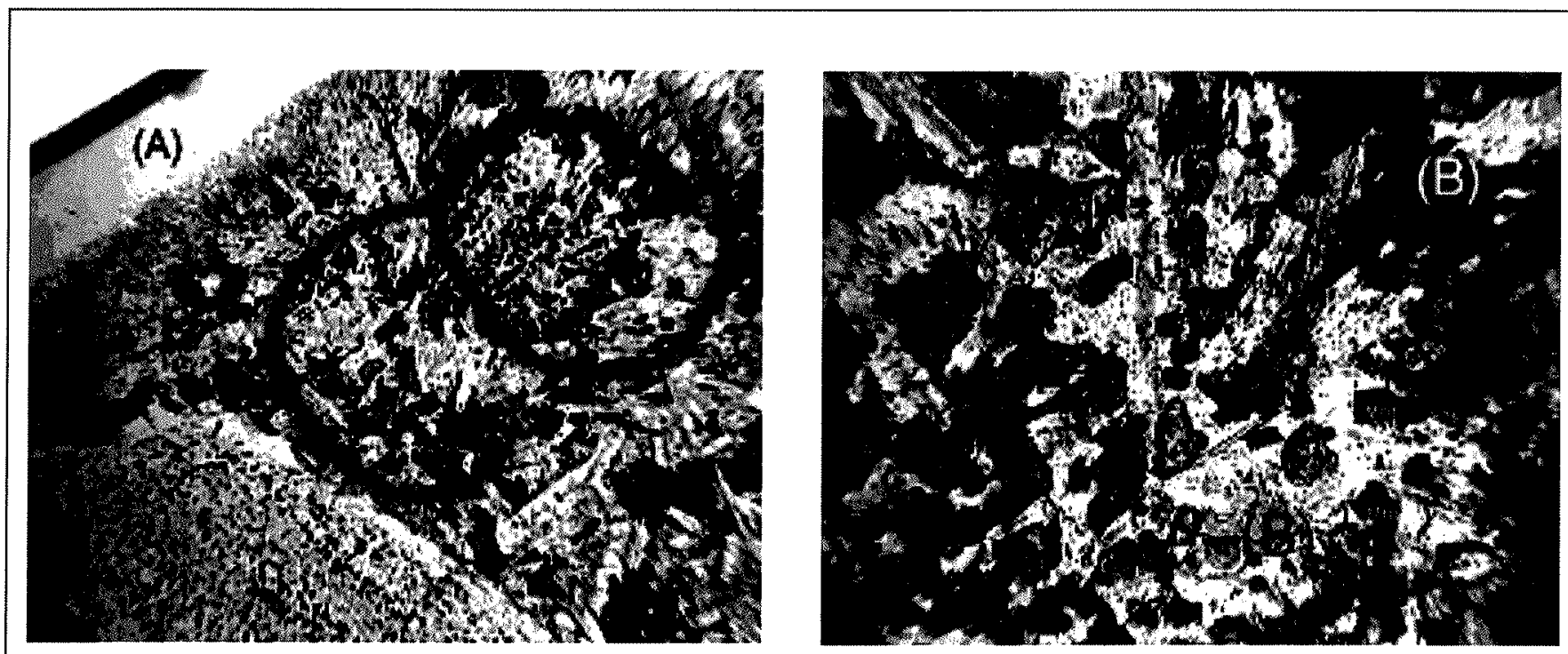

Figura 2-(A) Microenclave básico (dentro da marca circular superior) em andesito basáltico pórfiro (LN). (B) Detalhe do microenclave da Fig. 1 . $(L N)$ 

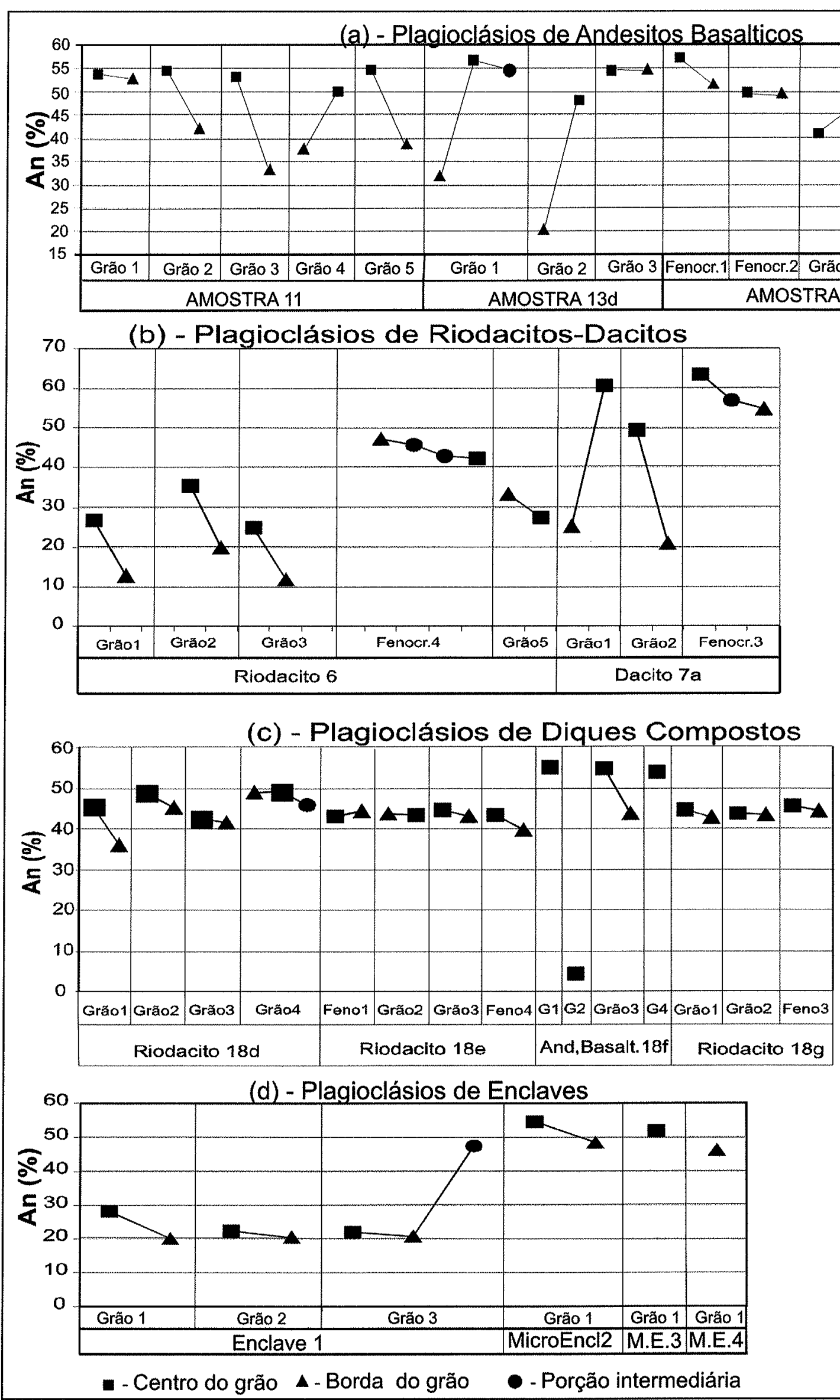

Figura 3 - Variação dos teores em An de plagioclásios: (a),em andesitos basálticos; (b) em riodacitos-dacitos; (c) em diques compostos; (d) em enclaves. 
da amostra 13b). Em apenas um caso (grão 3, da amostra 10) observou-se zonação inversa (núcleo $\mathrm{An}_{41}$ e borda $\mathrm{An}_{47}$ ).

Nos riodacitos-dacitos (Fig. $3 \mathrm{~b}$ ), o plagioclásio da matriz é menos cálcico; mostra-se zonado, com $\mathrm{An}_{24.35}$ no centro e $\mathrm{An}_{12-20}$ nas bordas. Observou-se um grão com zonação inversa (grão 5 do riodacito 6). Fenocristal analisado (fenocristal 4 do riodacito 6) mostra tênue zonação inversa $\left(\mathrm{An}_{42}\right.$ no centro e $\mathrm{An}_{47}$ na borda). Nos dacitos, o plagioclásio é mais cálcico, também zonado, com núcleo de labradorita $\left(\mathrm{An}_{50-60}\right)$ e bordas de oligoclásio $\left(\mathrm{An}_{20-25}\right)$. Fenocristais são mais cálcicos e mostram menor amplitude de zonação (núcleo $\mathrm{An}_{63}$, borda $\mathrm{An}_{54}$ ).

Nos riodacitos, de diques compostos (Fig. 3c), o plagioclásio é andesina, que geralmente ocorre quase sem zonação $\left(\mathrm{An}_{42}\right.$ $\left.{ }_{44}\right)$. Eventualmente observa-se zonação de pequena amplitude (núcleo $\mathrm{An}_{45}$, borda $\mathrm{An}_{35}$ - grão 1 do riodacito $18 \mathrm{~d}$ ). Nos andesitos basálticos de diques compostos, ocorre labradorita, $\mathrm{An}_{55}$, com borda menos cálcica $\left(\mathrm{An}_{43}\right)$.

Plagioclásio de enclaves e microenclaves de composição ácida podem exibir fenocristais com zonação aparentemente irregular (grão 3 do enclave 1 - figura 6d). Na matriz desses enclaves predomina oligoclásio com bordas menos cálcicas de $\mathrm{An}_{20-28}$ (grãos 1 e 2 do enclave 1). Nos enclaves de composição básico-intermediária, predomina labradorita ou andesina cálcica $\left(\mathrm{An}_{46-54}\right)$, por vezes com zonação de pequena amplitude (microenclaves 2, 3 e 4 - Fig. 3d).

Piroxênios Na Tabela 2 estão listadas amostras representativas de um total de 69 análises de piroxênio realizadas.

A classificação dos piroxênios no diagrama de Morimoto (1988) indica que todas as análises plotam no campo do Quad (Fig. 4).

Na Fig 5 são apresentados os piroxênios de andesitos basálticos, os quais plotam no campo da augita. Piroxênios de microenclaves, nessas rochas, mostram composição semelhante.

Os piroxênios de riodacitos (Fig. 6A) mostram-se muitas vezes zonados, com núcleos de pigeonita $\left(\mathrm{Wo}_{8} \mathrm{En}_{50} \mathrm{Fs}_{42}\right)$ e bordas de augita $\left(\mathrm{Wo}_{36} \mathrm{En}_{32} \mathrm{Fs}_{32}\right)$. Por vezes, a pigeonita do núcleo grada para pigeonita mais férrica, numa posição intermediária, que, por sua vez é manteada por borda de augita. Ocorrem, também, grãos de pigeonita sem zonação $\left(\mathrm{Wo}_{9} \mathrm{En}_{51} \mathrm{Fs}_{40}\right)$.

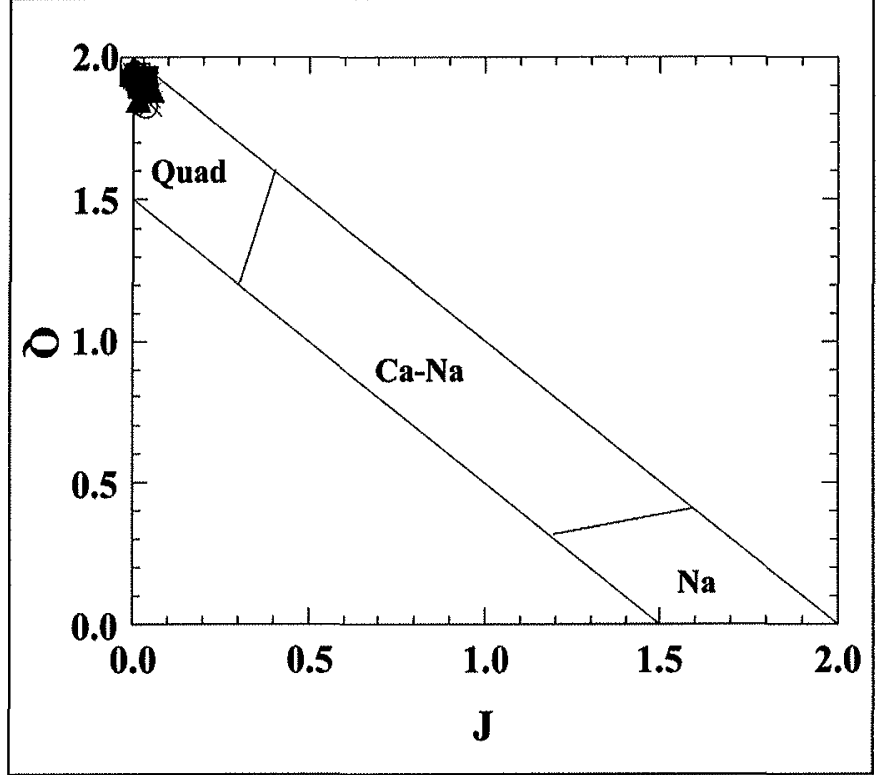

Figura 4 - Diagrama Quad $\left(\mathrm{Ca}+\mathrm{Mg}+\mathrm{Fe}^{+2}\right)$ versus $J(2 \mathrm{Na})$ do total de piroxênios analisados.
Nos dacitos (Figs. 6B e 6C) ocorrem, também dois tipos de piroxênio coexistentes: augita $\left(\mathrm{Wo}_{35-37} \mathrm{En}_{44-40} \mathrm{Fs}_{21-23}\right)$ e pigeonita ( $\mathrm{Wo}_{10} \mathrm{En}_{42} \mathrm{Fs}_{48}$ ), ambos mais magnesianos do que os dos riodacitos, sendo as augitas de composição semelhante a dos andesitos basálticos.

Riodacitos de diques compostos contém augita mais magnesiana, com muito pouca variação composicional (Fig. 7). Os andesitos basálticos de diques compostos analisados não apresentaram piroxênio, somente anfibólios, possivelmente como resultado de substituições tardimagmáticas.

$\mathrm{Na}$ Fig. 8 é apresentado o diagrama de variação do $\mathrm{MnO} \mathrm{em}$ augitas em função do valor de magnésio $(100 \mathrm{Mg} /$ $\mathrm{MgO}+\mathrm{FeO}+\mathrm{Fe}_{2} \mathrm{O}_{3}$ ). Em andesitos basálticos de diques (Fig. $8 \mathrm{~A}$ ), as augitas alinham-se segundo trend de inclinação negativa. Já as augitas de diques e corpos hipabissais de riodacitos/ dacitos (Fig. 8B), alinham-se segundo trend também de inclinação negativa, porém com ângulo de inclinação maior. Nesse diagrama, as augitas de microenclaves básicos em riodacitos mostram-se alinhados segundo o trend das dos andesitos basálticos. Isso aponta para uma possível relação de consangüinidade entre os microenclaves básicos e os andesitos basálticos, sinalizando para um processo de mistura magmática entre riodacitos e andesitos basálticos.

Anfibólios Os dados analíticos de amostras representativas de 50 análises de anfibólios estão listados na Tabela 3 . O cálculo da fórmula estrutural, bem como a classificação foram feitos com base nos procedimentos sugeridos por Leake et al. (1997).

Os anfibólios dos diversos litotipos da llha do Arvoredo são classificados como anfibólios cálcicos, como mostra o diagrama da Fig. 9.

Nos andesitos basálticos, os anfibólios são classificados como magnésio hornblenda, ferro hornblenda actinolita e ferro actinolita (Fig. 10). Podem ocorrer no entorno de augita, como produto de substituição parcial tardimagmática, ou como grãos minerais puros sem inclusões de piroxênio.

Nos riodacitos e dacitos ocorre actinolita, ferro hornblenda, magnésio hornblenda e edenita (Figs. 11 A e 11C) como produto de substituição tardimagmática de augita ou gedrita (11B) como produto da substituição de pigeonita.

Os anfibólios de riodacitos de diques compostos plotam no campo da actinolita, ferro actinolita, magnésio hornblenda, ferro hornblenda (Fig. 12A) e da edenita (Fig. 12C). Os de andesito basáltico de dique composto tendem a ser mais magnesianos e plotam no campo da actinolita e magnésio hornblenda (Fig. 12B).

$\mathrm{Na}$ Fig. 13 é apresentado o diagrama de variação de $\mathrm{Na}_{2} \mathrm{O}+\mathrm{K}_{2} \mathrm{O}$ versus valor de magnésio para anfibólios de dique composto. Observa-se, nos anfibólios dos riodacitos, um progressivo empobrecimento em álcalis associado com o aumento do teor em $\mathrm{Mg}$ do centro para a borda, onde o riodacito exibe discretas feições transicionais com o andesito basáltico da borda do dique.

Espinélios Os espinélios são classificados como magnetita e magnetita titanífera, com teores muito baixos em $\mathrm{Al}, \mathrm{Cr}, \mathrm{Mg}$, $\mathrm{Mn}$ e $\mathrm{Zn}$. Amostras representativas de 38 análises estão listadas na Tabela 4.

$\mathrm{Na}$ Fig. 14 são apresentados os diagramas triangulares $\mathrm{TiO}_{2}-$ $\mathrm{FeO}-\mathrm{Fe}_{2} \mathrm{O}_{3}$ que mostram as variações composicionais do espinélio em diversos litotipos.

Nos andesitos basálticos de diques simples (Fig. 14A), a magnetita é muito pouco titanífera, com índice Usp variando entre 0,1 e $4,9 \%\left(\mathrm{Usp}_{0,1-4,9}\right)$. Alguns diques exibem grãos de magnetita pura; em outros, ocorrem lamelas de de oxi-exolução de ilmenita, mostrando padrão do tipo treliça (Fig. 15A) ou do tipo sanduíche (Haggerty, 1991), como mostra a Figura 15B. 
Tabela 1-Análises Representativas de Plagioclásios

\begin{tabular}{|c|c|c|c|c|c|c|c|c|c|c|}
\hline \multirow{3}{*}{\begin{tabular}{|c|} 
Litotipo \\
Grão \\
Mineral \\
\end{tabular}} & \multicolumn{2}{|c|}{ Andesito Basáltico } & \multicolumn{2}{|c|}{ Dacito } & \multicolumn{2}{|c|}{ Riodacito } & \multicolumn{2}{|c|}{ Riodacito-Dq.Com. } & \multicolumn{2}{|c|}{ And.Bas.-Dq.Comp. } \\
\hline & \multicolumn{2}{|c|}{ G5 } & \multicolumn{2}{|c|}{ G1 } & \multicolumn{2}{|c|}{$\mathrm{G} 2$} & \multicolumn{2}{|c|}{ G3 } & \multicolumn{2}{|c|}{$\mathrm{G} 3$} \\
\hline & Labradorita & Andesina & Labradorita & Andesina & Andesina & Andesina & Andesina & Andesina & Labradorita & Andesina \\
\hline Posição & centro & borda & centro & borda & centro & centro & centro & borda & centro & borda \\
\hline Análise & 11c7p1 & $11 \mathrm{c} 7 \mathrm{p} 2$ & \begin{tabular}{|l|}
$13 \mathrm{e} 8 \mathrm{P} 1$ \\
\end{tabular} & 13E8P2 & $65 \mathrm{G} 2 \mathrm{P} 3$ & 67P4 & 18EC3P4 & 18EC3P5 & $18 \mathrm{fc5p1}$ & $18 f \mathrm{csp} 2$ \\
\hline SiO2 & 54,969 & 59,156 & 54,102 & 56,949 & 59,797 & 57,653 & 57,499 & 57,678 & 54,193 & 57,826 \\
\hline TiO2 & 0,261 & 0,201 & 0,287 & 0,133 & 0,133 & 0,153 & 0,053 & 0,200 & 0,141 & 0,100 \\
\hline Al2O3 & 27,936 & 25,571 & 28,617 & 27,110 & 24,839 & 25,786 & 26,448 & 25,907 & 28,016 & 26,126 \\
\hline $\mathrm{FeO}$ & 0,728 & 0,591 & 0,763 & 0,672 & 0,477 & 0,629 & 0,714 & 0,575 & 0,486 & 0,646 \\
\hline MgO & 0,110 & 0,033 & 0,086 & 0,028 & 0,008 & 0,032 & 0,005 & 0,006 & 0,003 & 0,004 \\
\hline $\mathrm{CaO}$ & 10,565 & 7,395 & 11,478 & 9,255 & 6,790 & 8,236 & 8,658 & 8,462 & 10,633 & 8,422 \\
\hline $\mathrm{Na2O}$ & 4,507 & 6,033 & 4,308 & 5,609 & 6,612 & 5,856 & 5,649 & 5,939 & 4,653 & 5,795 \\
\hline K2O & 0,411 & 0,812 & 0,510 & 0,133 & 0,282 & 0,516 & 0,410 & 0,315 & 0,311 & 0,316 \\
\hline Total & 99,59 & 99,94 & 100,15 & 100,1 & 99,09 & 98,95 & 99,50 & 99,44 & 98,53 & 99,24 \\
\hline \multicolumn{11}{|c|}{ Cátions com base em 8 oxigênios } \\
\hline $\mathbf{S i}$ & 2,492 & 2,648 & 2,448 & 2,557 & 2,687 & 2,612 & 2,592 & 2,605 & 2,482 & 2,608 \\
\hline Al & 1,491 & 1,348 & 1,525 & 1,434 & 1,314 & 1,376 & 1,404 & 1,378 & 1,511 & 1,388 \\
\hline $\mathbf{T i}$ & 0,009 & 0,007 & 0,010 & 0,004 & 0,004 & 0,005 & 0,002 & 0,007 & 0,005 & 0,003 \\
\hline $\mathrm{Fe} 2$ & 0,028 & 0,022 & 0,029 & 0,025 & 0,018 & 0,024 & 0,027 & 0,022 & 0,019 & 0,024 \\
\hline $\mathrm{Mg}$ & 0,007 & 0,002 & 0,006 & 0,002 & 0,001 & 0,002 & 0,000 & 0,000 & 0,000 & 0,000 \\
\hline Ba & 0,002 & 0,003 & 0,000 & 0,004 & 0,003 & 0,001 & 0,001 & 0,006 & 0,002 & 0,000 \\
\hline $\mathbf{C a}$ & 0,513 & 0,355 & 0,556 & 0,445 & 0,327 & 0,400 & 0,418 & 0,409 & 0,522 & 0,407 \\
\hline $\mathbf{N a}$ & 0,396 & 0,524 & 0,378 & 0,488 & 0,576 & 0,514 & 0,494 & 0,520 & 0,413 & 0,507 \\
\hline $\mathbf{K}$ & 0,024 & 0,046 & 0,029 & 0,008 & 0,016 & 0,030 & 0,024 & 0,018 & 0,018 & 0,018 \\
\hline \begin{tabular}{|l|} 
Cations \\
\end{tabular} & 4,96 & 4,96 & 4,98 & 4,97 & 4,95 & 4,96 & 4,96 & 4,96 & 4,97 & 4,95 \\
\hline $\mathbf{A b}$ & 42,44 & 56,65 & 39,25 & 51,86 & 62,68 & 54,45 & 52,78 & 54,91 & 43,34 & 54,4 \\
\hline An & 54,98 & 38,38 & 57,74 & 47,29 & 35,58 & 42,37 & 44,66 & 43,19 & 54,77 & 43,67 \\
\hline $\mathrm{Or}$ & 2,57 & 4,97 & 3,01 & 0,85 & 1,74 & 3,18 & 2,56 & 1,9 & 1,89 & 1,93 \\
\hline
\end{tabular}

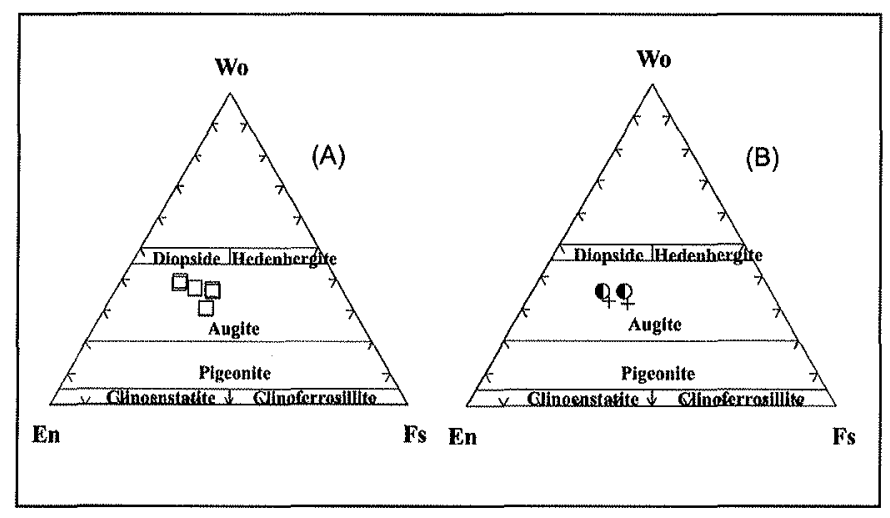

Figura 5-Piroxênios de diques básicos. Símbolos: quadradosandesito basáltico-amostra 11; circulos semi-preenchidos-andesito basáltico-amostra 10; cruzes-microenclaves da amostra 10.

Riodacitos de diques simples (Fig. 14B) apresentam magnetita com teores mais elevados em Ti (Usp $\left.{ }_{19-37}\right)$ do que os andesitos basálticos. Os grãos exibem freqüentemente lamelas de oxi-exolução de ilmenita com padrão do tipo treliça. Quando essas lamelas são mais numerosas, o teor em Ti tende a cair, deixando o índice Usp em torno de 19\%, indicando que os teores de Ti parecem estar relacionados ao grau de oxidação das magnetitas titaníferas.

Nos diques compostos, os riodacitos (Fig. 14C) apresentam, também, magnetita titanífera, com índice Usp variando entre $8 \%$ e $38 \%\left(\mathrm{Usp}_{8-38}\right)$. Lamelas de oxi-redução de ilmenita com

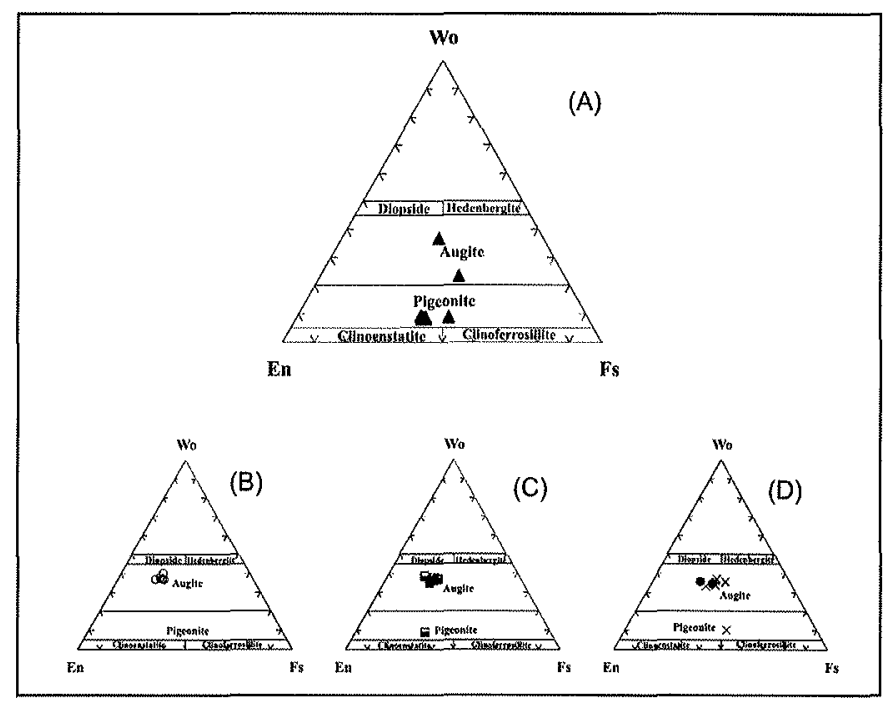

Figura 6-Diagramas Wo-En-Fs, onde estão representadas as composições de piroxênios de diversas amostras de riodacito $e$ dacito de diques e corpos hipabissais. $(A)$ riodacito; $(B)$ dacito; (C) dacito; (D) microenclaves no dacito.

padrão do tipo treliça ou sanduíche também ocorrem.

Andesitos basálticos de diques compostos (Fig. 14D), apresentam magnetitas com baixos teores médios em Ti (Usp $\left.{ }_{0,4-35}\right)$. Análise isolada acusou a presença de grão de magnetita titanífera $\left(\mathrm{Usp}_{36}\right)$, mostrando que há grandes flutuações no teor em Ti, 
Tabela 2 - Análises representativas de piroxênios de andesito basáltico,dacito, riodacito e riodacito de dique composto.

\begin{tabular}{|c|c|c|c|c|c|c|c|}
\hline \multirow{3}{*}{$\begin{array}{l}\text { Litotipo } \\
\text { Grão } \\
\text { Mineral } \\
\end{array}$} & \multirow{2}{*}{\multicolumn{2}{|c|}{\begin{tabular}{|l|} 
Andesito basáltico \\
G1 \\
\end{tabular}}} & \multicolumn{2}{|l|}{ Dacito } & \multirow{2}{*}{\multicolumn{2}{|c|}{$\begin{array}{l}\text { Riodacito } \\
\text { Gl } \\
\end{array}$}} & \multirow{3}{*}{\begin{tabular}{|l} 
Rd.dq comp. \\
G2 \\
augita \\
\end{tabular}} \\
\hline & & & \multirow{2}{*}{\begin{tabular}{|l|}
$\mathrm{G} 2$ \\
pigeonita \\
\end{tabular}} & \multirow{2}{*}{\begin{tabular}{|l|} 
G3 \\
augita \\
\end{tabular}} & & & \\
\hline & augita & augita & & & pigeonita & augita & \\
\hline Posição & centro & borda & centro & borda & centro & borda & interm, \\
\hline Análise & $11 \mathrm{clp} 1$ & $11 \mathrm{c} 1 \mathrm{p} 2$ & 7А3BP2 & 7AC4P1 & $6 \mathrm{C} 1 \mathrm{P2}$ & $6 \mathrm{C} 1 \mathrm{P3}$ & $18 \mathrm{GC} 4 \mathrm{P3}$ \\
\hline SiO2 & 50,054 & 49,648 & 52,195 & 51,207 & 51,664 & 50,748 & 50,362 \\
\hline TiO2 & 1,064 & 0,813 & 0,404 & 0,836 & 0,518 & 0,75 & 0,751 \\
\hline Al2O3 & 1,824 & 1,856 & $0, \overline{778}$ & 1,712 & 0,644 & 1,310 & 1,241 \\
\hline $\mathrm{FeO}$ & 15,182 & 13,777 & 19,155 & 12,265 & 23,916 & 16,871 & 13,301 \\
\hline Fe2O3 & 2,073 & 2,587 & 1,099 & 1,658 & 0,684 & 1,400 & 2,394 \\
\hline $\mathrm{MnO}$ & 0,428 & 0,431 & 0,582 & 0,347 & 1,062 & 0,732 & 0,731 \\
\hline NiO & 0 & 0 & 0 & 0 & 0 & 0,013 & 0 \\
\hline $\mathrm{MgO}$ & 14,163 & 12,476 & 20,974 & 14,576 & 17,628 & 11,035 & 13,179 \\
\hline $\mathrm{CaO}$ & 14,863 & 17,249 & 4,360 & 17,714 & 4,312 & 17,482 & 17,340 \\
\hline $\mathrm{Na2O}$ & 0,193 & 0,307 & 0 & 0,147 & 0,067 & 0,35 & 0,248 \\
\hline $\mathrm{K2O}$ & 0,005 & 0,042 & 0,021 & 0,004 & 0 & 0,015 & 0 \\
\hline Total & 99,86 & 99,22 & $\mathbf{9 9 , 5 7}$ & 100,47 & 100,5 & 100,71 & 99,55 \\
\hline \multicolumn{8}{|c|}{ Fórmula estrutural com base em 6 oxigênios } \\
\hline TSi & 1,906 & 1,909 & 1,956 & 1,921 & 1,963 & 1,942 & 1,925 \\
\hline TAI & 0,082 & 0,084 & 0,034 & 0,076 & 0,029 & 0,058 & 0,056 \\
\hline TFe3 & 0,012 & 0,007 & 0,009 & 0,004 & 0,008 & 0 & 0,019 \\
\hline M1Al & 0 & 0 & 0 & 0 & 0 & 0,001 & 0 \\
\hline M1Ti & 0,03 & 0,024 & 0,011 & 0,024 & 0,015 & 0,022 & 0,022 \\
\hline M1Fe3 & 0,047 & 0,068 & 0,022 & 0,043 & 0,012 & 0,04 & 0,05 \\
\hline M1Fe2 & 0,118 & 0,193 & 0 & 0,118 & 0 & 0,307 & 0,177 \\
\hline M1Mg & 0,804 & 0,715 & 0,967 & 0,815 & 0,973 & 0,63 & 0,751 \\
\hline MiNi & 0 & 0 & 0 & 0 & 0 & 0 & 0 \\
\hline M2Mg & 0 & \begin{tabular}{|l|}
0 \\
\end{tabular} & 0,205 & 0 & 0,025 & 0 & 0 \\
\hline $\mathrm{M} 2 \mathrm{Fe} 2$ & 0,365 & 0,25 & 0,6 & 0,266 & 0,76 & 0,233 & 0,248 \\
\hline M2Mn & 0,014 & 0,014 & 0,018 & 0,011 & 0,034 & 0,024 & 0,024 \\
\hline M2Ca & 0,606 & 0,711 & 0,175 & 0,712 & 0,176 & 0,717 & 0,71 \\
\hline $\mathrm{M} 2 \mathrm{Na}$ & 0,014 & 0,023 & 0 & 0,011 & 0,005 & 0,026 & 0,018 \\
\hline M2K & 0 & 0,002 & 0,001 & 0 & 0 & 0,001 & 0 \\
\hline Sum_cat & 4 & 4 & 4 & 4 & 4 & 4 & 4 \\
\hline WO & \begin{tabular}{|l|}
30,828 \\
\end{tabular} & 36,3 & 8,768 & \begin{tabular}{|l|}
36,147 \\
\end{tabular} & \begin{tabular}{|l|}
8,831 \\
\end{tabular} & 36,753 & \begin{tabular}{|l|}
$\mathbf{3 5 , 8 8 8}$ \\
\end{tabular} \\
\hline EN & 40,874 & $\mathbf{3 6 , 5 3 2}$ & 58,688 & 41,385 & 50,234 & 32,28 & 37,952 \\
\hline FS & 28,298 & 27,168 & 32,544 & 22,469 & 40,935 & 30,967 & 26,16 \\
\hline
\end{tabular}

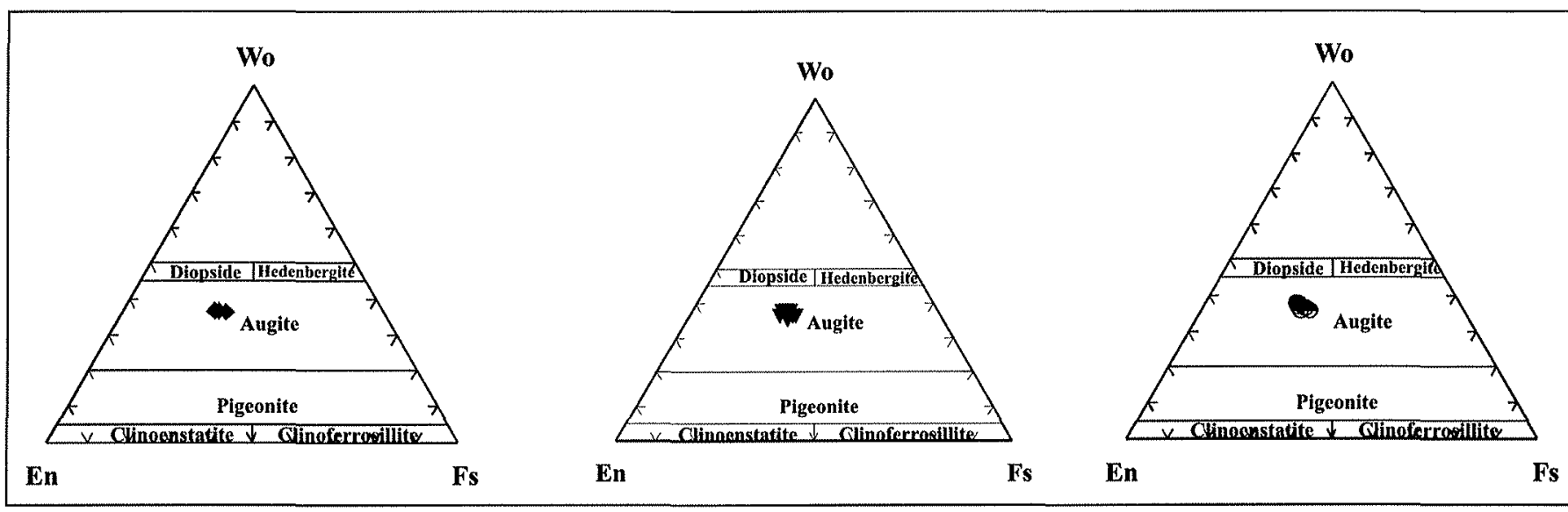

Figura 7-Piroxênios de riodacitos de diques compostos, (A) amostra 18d; (B) amostra 18e; (C) amostra 18g 


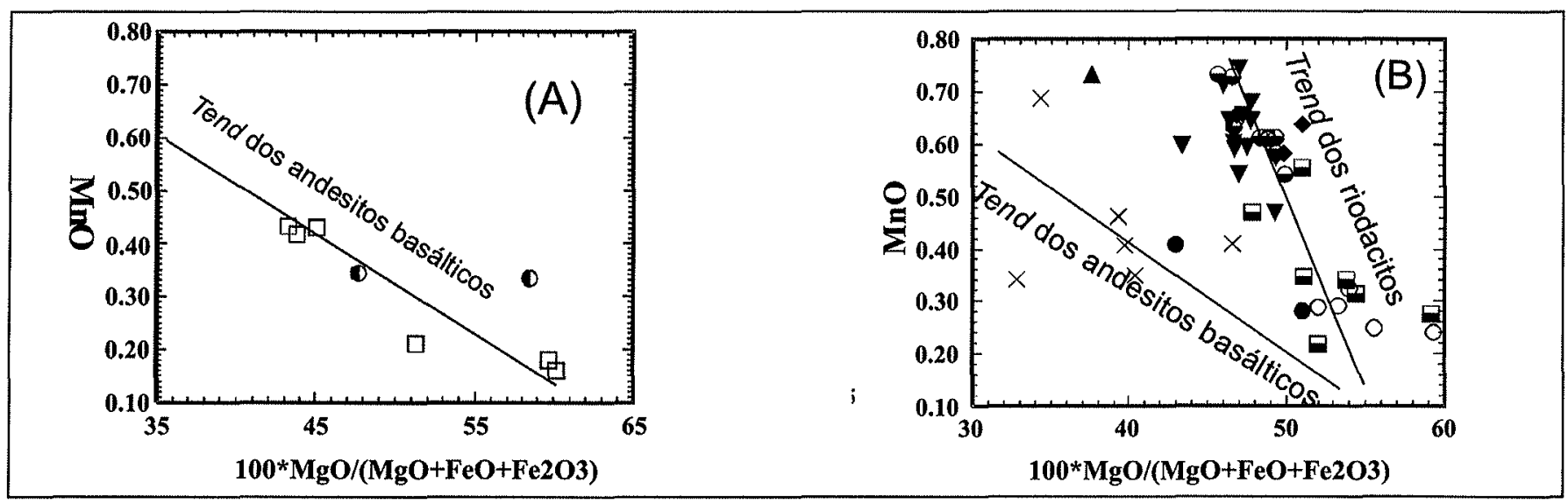

Figura 8-(A) Diagrama de variação do MnO em augitas de andesitos basálticos; (B) em augitas de riodacitos/dacitos (triângulos, quadrados, circulos e losangos) e em augitas de microenclaves básicos (símbolos em X). Os microenclaves mostram alinhamento segundo o trend dos andesitos basálticos.

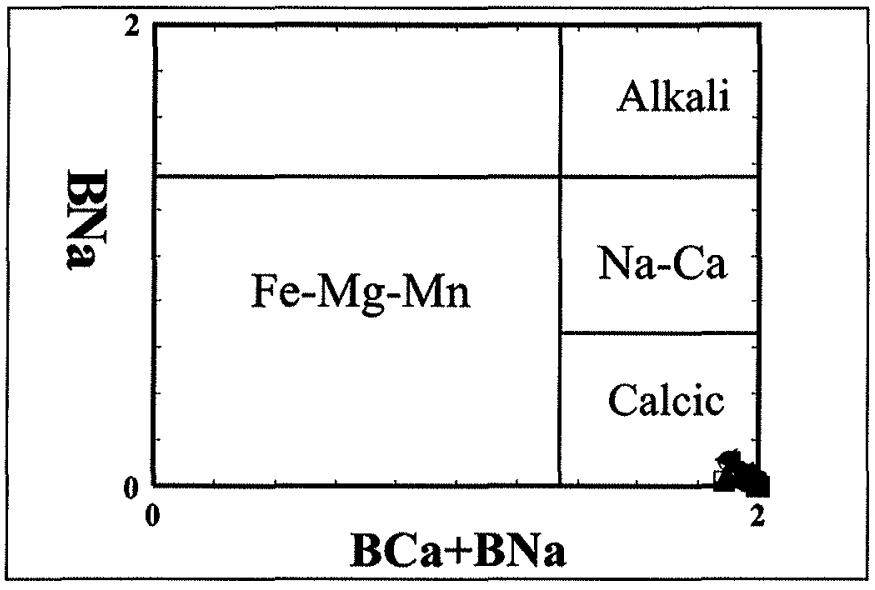

Figura 9 - Classificação geral dos anfibólios da Ilha do Arvoredo.

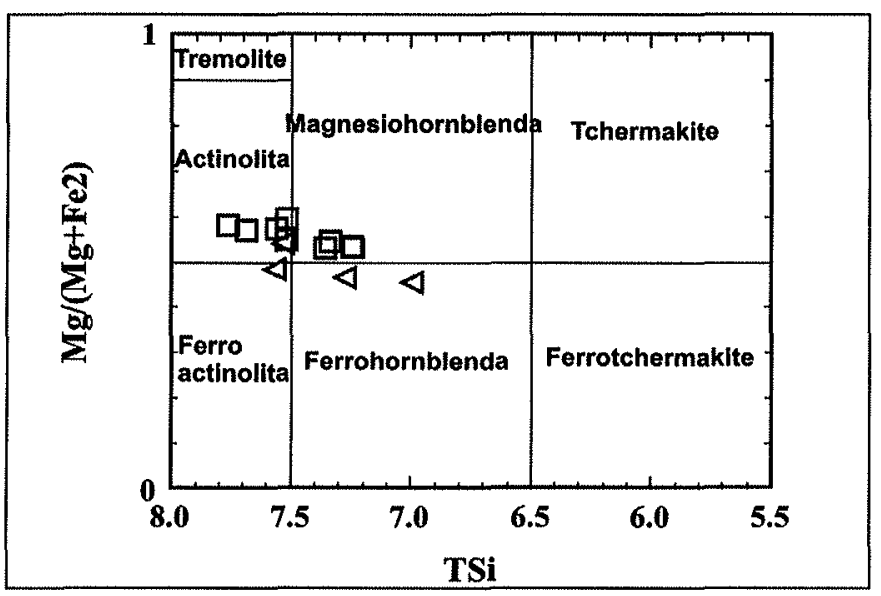

Figura 10-Anfibólios de andesitos basálticos.

provavelmente relacionadas ao grau de oxidação.

Ilmenitas As ilmenitas, cujos resultados analíticos de amostras selecionadas de 51 análises, estão listados na Tabela 5, apresentam relativamente pouca variação composicional, que pode ser visualizada nos diagramas triangulares $X_{\mathrm{il}}-X_{\mathrm{hem}}-X_{\mathrm{py}}$, da Fig. 16. Nestes diagramas, $X_{\mathrm{il}}$ representa a fração molar de ilmenita $\left(\mathrm{FeTiO}_{3}\right), X_{\text {hem }}$ a da hematita $\left(\mathrm{Fe}_{2} \mathrm{O}_{3}\right)$ e $X_{\text {py }}$ a da pyrophanita $\left(\mathrm{MnTiO}_{3}\right)$. Como as frações molares da geikielita $\left(\mathrm{MgTiO}_{3}\right)$ são muito baixas, preferiu-se desconsiderar esse componente na avaliação das variações composicionais da ilmenita.

LITOGEOQUÍMICA Na Tabela 6 são apresentados os resultados analíticos de amostras de rocha representativas de 16 amostras analisadas. Os elementos maiores e traços foram analisados no Laboratório de Geoquímica do Centro de Pesquisa em Geoquímica - CPGq-UFRGS utilizando-se o método de espectroscopia de fluorescência de R-X, associado com o método de espectrometria de absorção atômica, As análises de elementos terras raras foram realizadas no Laboratório de Análise por Ativação Neutrônica do Instituto de Pesquisas Energéticas e Nucleares - IPEN.

Classificação química No diagrama $\mathrm{Na}_{2} \mathrm{O}+\mathrm{K}_{2} \mathrm{O}$ versus $\mathrm{SiO}_{2}$ (Fig. 17A), de Le Bas et al. (1986) ou no diagrama $\mathrm{SiO}_{2}$ versus $\mathrm{Zr} / \mathrm{TiO}_{2}$ (Fig. 17B), de Winchester \& Floyd (1977), as amostras plotam nos campos correspondentes a andesito/andesito-traquiandesito basáltico basáltico, riodacito/dacito-traquidacito e riolito.

Comportamento geoquímico dos elementos Na Fig. 18 são apresentados os diagramas de variação para elementos maiores e elementos traços, utilizando-se $\mathrm{SiO}_{2}$ como índice de diferenciação.

Observa-se que para quase todos os óxidos, os diagramas apresentam uma grande linearidade, com a ausência de inflexões indicativas do fracionamento de alguma fase minerais, Essa é uma característica apontada por diversos autores ( $\mathrm{p}$, ex, Didier \& Barbarin, 1991) com indicativa de processo de mistura magmática.

As amostras de granito, riolitos de dique e aplitos de veio, mesmo sendo mais diferenciadas do que os riodacitos e dacitos, exibem acentuada queda nos teores em elementos como $\mathrm{Ba}, \mathrm{Zr}$ e Y, sugerindo tratar-se de grupos geoquímicos diversos.

Avaliação das séries magmáticas Todas as amostras analisadas mostram caráter subalcalino, como mostra o diagrama $\mathrm{Na}_{2} \mathrm{O}+\mathrm{K}_{2} \mathrm{O}$ versus $\mathrm{SiO}_{2}$ (Fig. 17A). No diagrama AFM (Fig. 19), as amostras plotam segundo um trend toleítico bem definido.

Andesitos basálticos de diques simples, assim como os de 


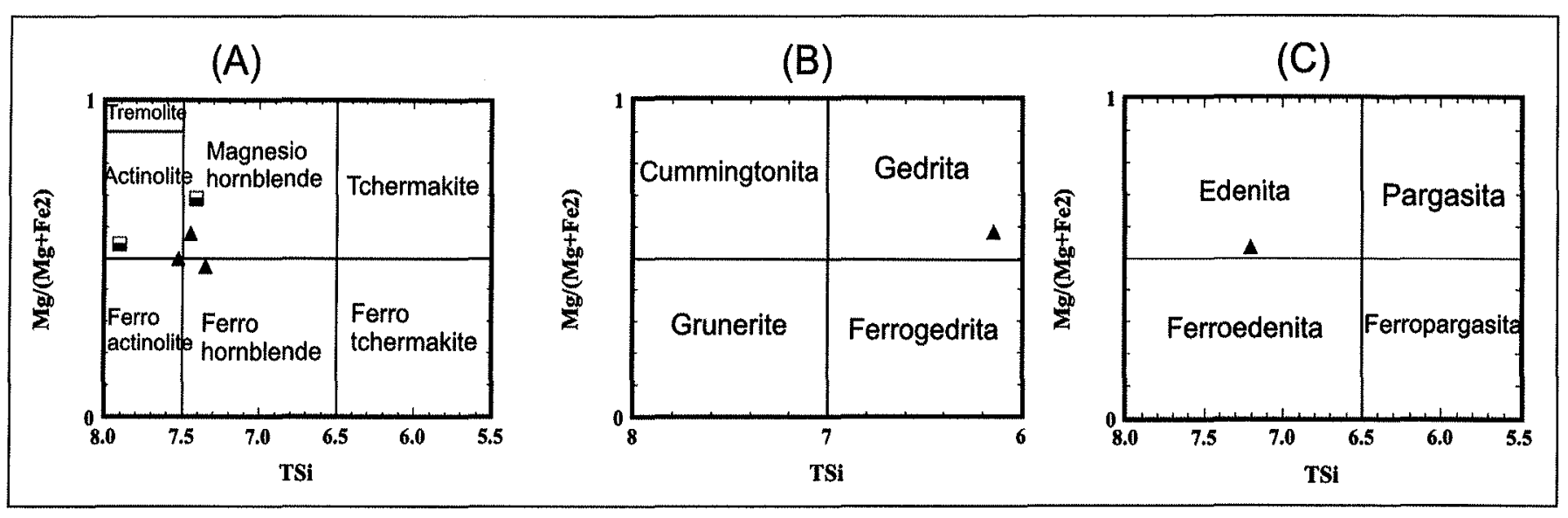

Figura 11 - Anfibólios de riodacito (triângulos) e dacito (quadrados).

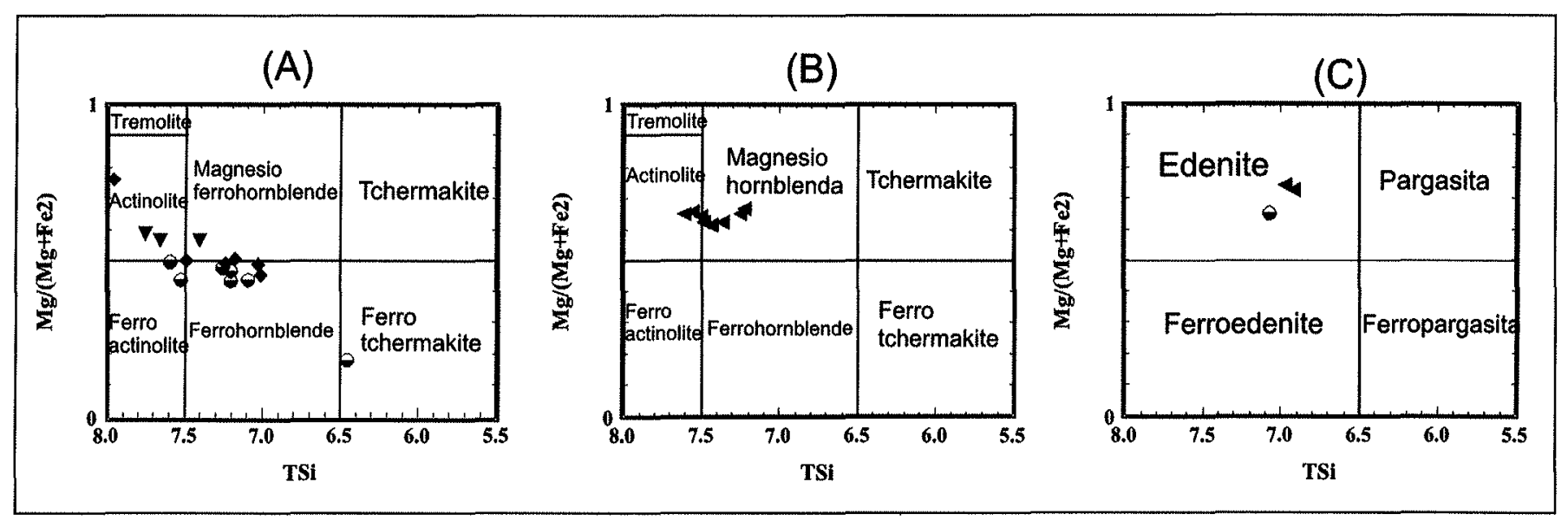

Figura 12 - (A)-anfibólios de riodacitos de dique composto; (B)-anfibólios de andesito de dique composto; (C) edenitas de riodacito (círculo semi-preenchido) e de andesito de dique composto (triângulo c/vértice à esquerda).

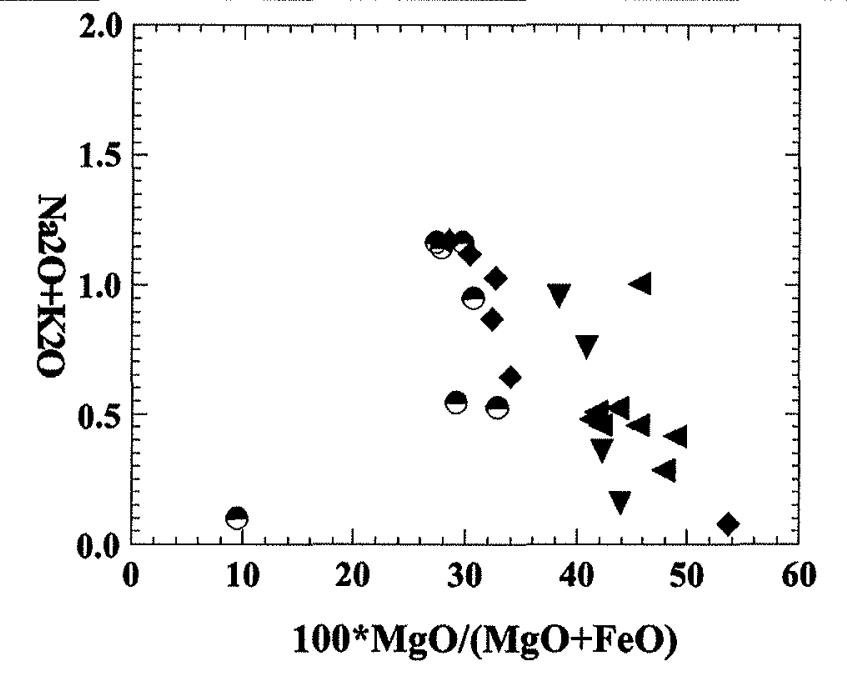

Figura 13 - Diagrama de variação de $\mathrm{Na}{ }_{2} \mathrm{O}+\mathrm{K}_{2} \mathrm{O}$ versus valor de Mg para anfibólios de dique composto. Simbolos: triângulos com vértice à esquerda - andesito basáltico da borda do dique composto; losangos e triângulos c/ vértice p/baixo-riodacitos de dique composto, quase no contato com o andesito basáltico; círculos semi-preenchidos-riodacito do centro do dique composto. diques compostos são rochas com alto $\mathrm{TiO}_{2}$ (3,2 a 3,7\%), enriquecidas em $\mathrm{K}_{2} \mathrm{O}$. São toleíticos, como mostram os diagramas índice de alcalinidade, IA versus $\mathrm{Al}_{2} \mathrm{O}_{3}$ (Middlemost, 1975) e FeOt/MgO versus $\mathrm{SiO}_{2}$ (Miyashiro, 1974), nas Figs. 20A e 20B. Trata-se, portanto de toleítos de alto Ti, $\mathrm{K}$ e bastante enriquecidos em elementos-traço incompatíveis. Assemelham-se aos basaltos de alto Ti de idade cretácea, que ocorrem na Bacia do Paraná-Etendeka e a diques de diabásio, também de idade cretácea, que ocorrem mais a sul, na llha de Santa Catarina (Fig. 1A), pertencentes ao Enxame de Diques Florianópolis. Esse enxame é aqui representado pelas amostras PM48a e PM48b (Tabela 6) pertencentes a dique básico na Ilha de Santa Catarina, previamente datado por Raposo et al, (1998), que obtiveram, nesse dique, idade de $123,3 \pm 0,5 \mathrm{Ma}$ (Cretáceo Superior), utilizando o método ${ }^{40} \mathrm{Ar} /{ }^{39} \mathrm{Ar}$.

Elementos Terras Raras (ETR) de andesitos basálticos (Fig. 21A) mostram um padrão de comportamento muito semelhante ao dos ETR das amostras de diabásios do Enxame de Diques Florianópolis acima mencionadas (Fig. 21C).

Spidergram (segundo o modelo de Sun, 1980) de andesitos basálticos (Fig. 21B), exibe assinatura muito semelhante à de

toleítos de ilhas oceânicas (OIT). O spidergram dos diabásios do Enxame de Diques Florianópolis (Fig. 21D), mostra elevado

grau de congruência com o dos andesitos basálticos da Ilha do Arvoredo. 
Tabela 3 - Análises •representativasdeAnfibóliosrepresentativassdeAnfibólios de Anfibólios

\begin{tabular}{|c|c|c|c|c|c|c|c|c|c|}
\hline \multirow{2}{*}{$\begin{array}{l}\text { Litotipo } \\
\text { Posição } \\
\end{array}$} & \multirow{2}{*}{$\begin{array}{l}\text { AndesBasál } \\
\text { borda }\end{array}$} & \multirow[b]{2}{*}{ centro } & \multicolumn{3}{|l|}{ Riodacitos } & \multicolumn{2}{|c|}{ Riodac./Dq.Composto } & \multicolumn{2}{|c|}{ And,Bas./Dq,Comp. } \\
\hline & & & & & & borda & centro & centro & centro \\
\hline Mineral & Actinolita & Mg-hornbl. & Fe-hornbl. & $\begin{array}{l}\text { Actinolit } \\
\text { a }\end{array}$ & Edenita & Actinolita & Fe-hornbl, & Mg-hornbl & Mg-hornbl \\
\hline Análise & $11 \mathrm{c10p2}$ & $11 \mathrm{c9p2}$ & 63DP2 & 6C1P4 & 6C2P6 & 18D3P1 & 18D4P2 & $18 \mathrm{fc} 3 \mathrm{p} 2 \mathrm{a}$ & $18 \mathrm{fc} 6 \mathrm{p} 1 \mathrm{a}$ \\
\hline $\mathrm{SiO2}$ & 52,024 & 49,1 & 48,197 & 49,621 & 46,996 & 51,905 & 46,475 & 51,013 & 50,221 \\
\hline TiO2 & 0,302 & 0,378 & 0,415 & 0,586 & 0,849 & 0,104 & 0,262 & 0,186 & 0,244 \\
\hline $\mathrm{Al2O3}$ & 1,691 & 4,014 & 3,793 & 1,154 & 4,762 & 0,467 & 6,355 & 3,604 & 3,557 \\
\hline $\mathrm{FeO}$ & 18,42 & 19,685 & 21,951 & 20,593 & 21,577 & 10,483 & 21,113 & 16,724 & 17,494 \\
\hline MnO & 0,266 & 0,23 & 0,605 & 0,823 & 0,576 & 0,59 & 0,508 & 0,24 & 0,173 \\
\hline $\mathrm{MgO}$ & 12,257 & 11,067 & 9,328 & 9,371 & 10,039 & 12,17 & 9,199 & 12,951 & 12,559 \\
\hline $\mathrm{CaO}$ & 12,223 & 11,893 & 11,241 & 17,26 & 8,384 & 22,557 & 12,225 & 12,133 & 12,098 \\
\hline $\mathrm{Na2O}$ & 0,224 & 0,543 & 0,372 & 0,263 & 0,071 & 0,083 & 0,603 & 0,307 & 0,345 \\
\hline $\mathrm{K2O}$ & 0,088 & 0,349 & 0,736 & 0 & 3,327 & 0 & 0,517 & 0,215 & 0,166 \\
\hline $\mathbf{F}$ & 0,005 & 0 & 0,243 & 0,029 & 0,196 & 0 & 0,106 & 0,097 & 0,005 \\
\hline $\mathrm{Cl}$ & 0,013 & 0,029 & 0 & 0 & 0 & 0,025 & 0,13 & 0,013 & 0,052 \\
\hline $\mathrm{H2O}$ & 2,012 & 1,981 & 1,827 & 1,978 & 1,837 & 2,033 & 1,874 & 1,978 & 1,991 \\
\hline Total & $\mathbf{9 9 , 5 3}$ & 99,27 & 98,71 & 101,68 & 98,61 & 100,42 & 99,37 & 99,46 & 98,9 \\
\hline \multicolumn{10}{|c|}{ Fórmula Estrutural com base em 23 oxigênios } \\
\hline TSi & 7,69 & 7,339 & 7,35 & 7,527 & 7,204 & 7,959 & 7,033 & 7,485 & 7,433 \\
\hline TAI & 0,293 & 0,661 & 0,642 & 0,206 & 0,738 & 0,04 & 0,967 & 0,515 & 0,567 \\
\hline TFe3 & 0,017 & 0 & 0,008 & 0,244 & 0,058 & 0,221 & 0 & 0 & 0 \\
\hline TTi & 0 & 0 & 0 & 0,034 & 0 & 0 & 0 & 0 & 0 \\
\hline Sum_T & 8 & 8 & 8 & 8,012 & 8 & 8,22 & 8 & 8 & 8 \\
\hline CAl & 0,002 & 0,046 & 0,039 & 0 & 0,122 & 0,045 & 0,166 & 0,108 & 0,053 \\
\hline $\mathrm{CFe} 3$ & 0,229 & 0,408 & 0,437 & 0,242 & 0,708 & 0,238 & 0,483 & 0,337 & 0,417 \\
\hline CTi & 0,034 & 0,043 & \begin{tabular}{|l|}
0,048 \\
\end{tabular} & 0,032 & 0,098 & 0,012 & 0,03 & 0,021 & 0,027 \\
\hline $\mathrm{CMg}$ & 2,701 & 2,466 & 2,121 & 2,119 & 2,294 & 2,782 & 2,075 & 2,833 & 2,771 \\
\hline $\mathrm{CFe} 2$ & 2,018 & 2,023 & 2,317 & 2,126 & 1,742 & 0,885 & 2,189 & 1,686 & 1,721 \\
\hline CMn & 0,017 & 0,015 & 0,039 & 0,106 & 0,037 & 0,077 & 0,057 & 0,015 & 0,011 \\
\hline $\mathrm{CCa}$ & 0 & 0 & 0 & 0,374 & 0 & 0,961 & 0 & 0 & 0 \\
\hline Sum_C & 5 & 5 & 5 & 5 & 5 & 5 & 5 & 5 & 5 \\
\hline BMg & 0 & 0 & 0 & 0 & 0 & 0 & 0 & 0 & 0 \\
\hline BFe2 & 0,013 & 0,03 & 0,037 & 0 & 0,258 & 0 & 0 & 0,028 & 0,027 \\
\hline BMn & 0,017 & 0,015 & \begin{tabular}{|l}
0,039 \\
\end{tabular} & 0 & 0,038 & 0 & 0,008 & 0,015 & 0,011 \\
\hline BCa & 1,936 & 1,905 & 1,837 & 2 & 1,377 & 2 & 1,982 & \begin{tabular}{|l|}
1,907 \\
\end{tabular} & 1,918 \\
\hline $\mathrm{BNa}$ & 0,032 & 0,051 & 0,055 & 0 & 0,01 & 0 & 0,01 & 0,044 & 0,044 \\
\hline Sum_B & 1,998 & 2 & 1,968 & 2 & 1,683 & 2 & 2 & 1,994 & 2 \\
\hline $\mathrm{ACa}$ & 0 & 0 & 0 & 0,431 & 0 & 0,745 & 0 & 0 & 0 \\
\hline $\mathbf{A N a}$ & 0,032 & 0,106 & 0,055 & 0,077 & 0,011 & 0,025 & 0,167 & 0,044 & 0,055 \\
\hline AK & 0,017 & 0,067 & 0,143 & 0 & 0,651 & 0 & 0,1 & 0,04 & 0,031 \\
\hline Sum_A & 0,049 & 0,173 & 0,198 & 0,508 & 0,661 & 0,769 & 0,267 & 0,084 & 0,087 \\
\hline Sum_cat & 15,047 & 15,173 & 15,166 & 15,52 & 15,345 & 15,99 & 15,267 & 15,078 & 15,087 \\
\hline $\mathrm{CCl}$ & 0,003 & 0,007 & 0 & 0 & 0 & 0,007 & 0,033 & 0,003 & 0,013 \\
\hline $\mathrm{CF}$ & 0,002 & 0 & 0,117 & 0,014 & 0,095 & 0 & 0,051 & 0,045 & 0,002 \\
\hline \multicolumn{10}{|l|}{ OH } \\
\hline Sum_oxy & 23 & 23 & 23 & 23,422 & 23,124 & 24,221 & 23 & 23 & 23 \\
\hline
\end{tabular}




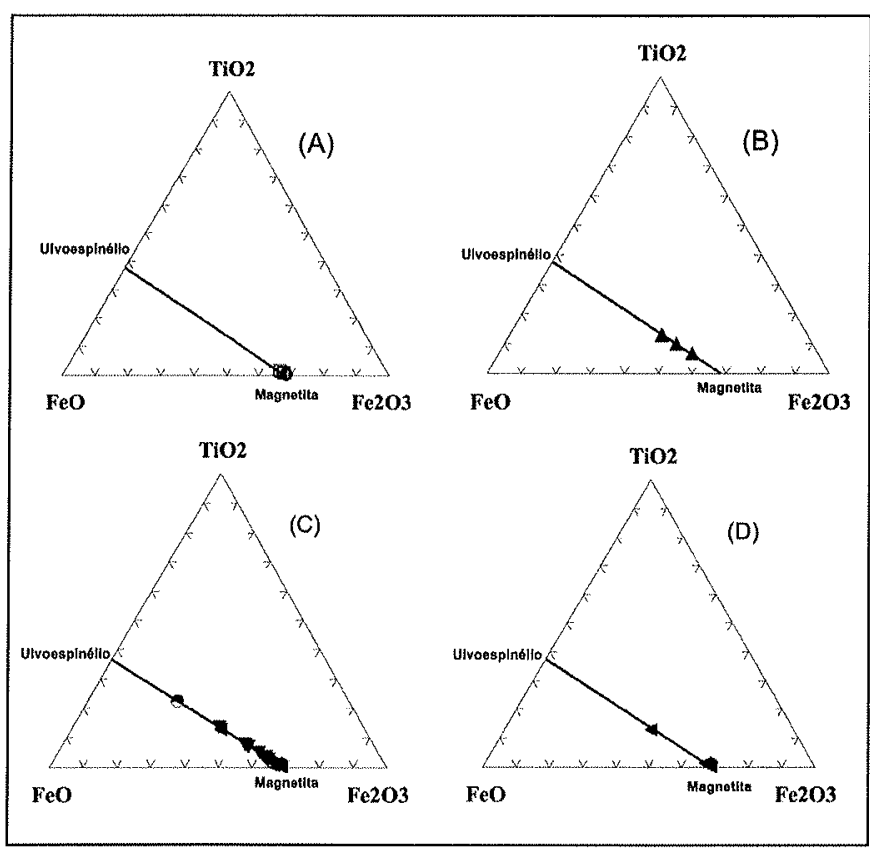

Figura 14 - Diagramas $\mathrm{TiO}_{2}-\mathrm{FeO}-\mathrm{Fe}_{2} \mathrm{O}_{3}$ mostrando as variações composicionais de espinélio. (A) em andesitos basálticos de dique simples; $(B)$ em riodacitos de dique simples; $(C)$ em riodacito de dique composto; (D) em andesito basáltico de dique composto.

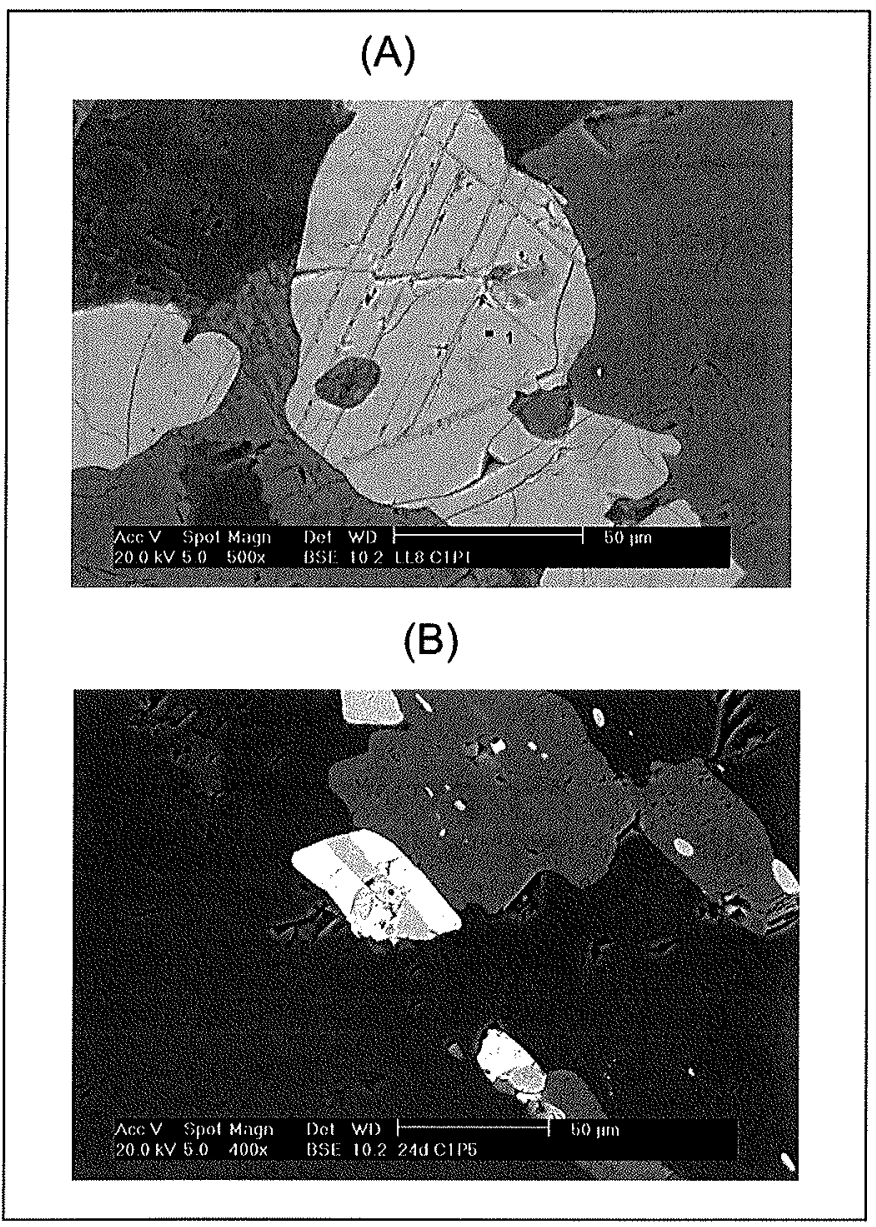

Figura 15 - Lamelas de oxi-exolução de ilmenita em magnetita (bandas mais escuras). (A) Tipo em treliça; (B) tipo sanduiche, Imagens de retroespalhamento de elétrons em $M E V$.

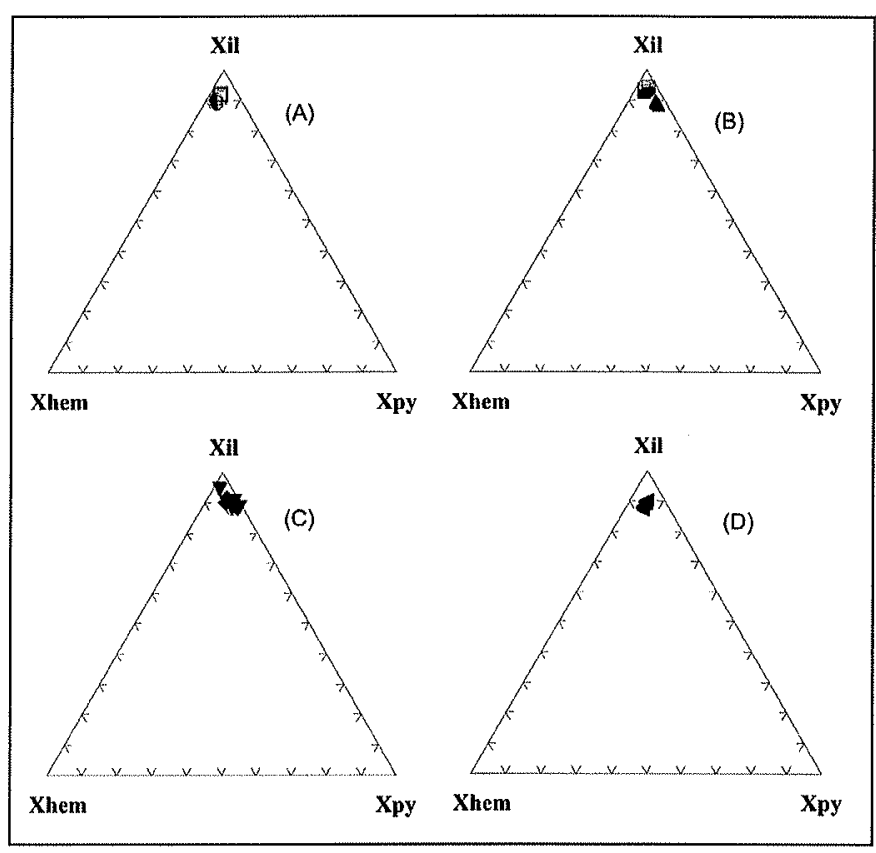

Figura 16 - Variação composicional da ilmenita em diversos litotipos, mostrada em diagramas triangulares $X_{i l}-X_{h e m}-X_{p i^{*}}(A)$ - Variação composicional da ilmenita em andesitos basálticos de diques simples; $(B)$ - em riodacitos de diques simples; $(C)$ - em riodacitos de dique composto, (D) - em andesito basáltico de dique composto.

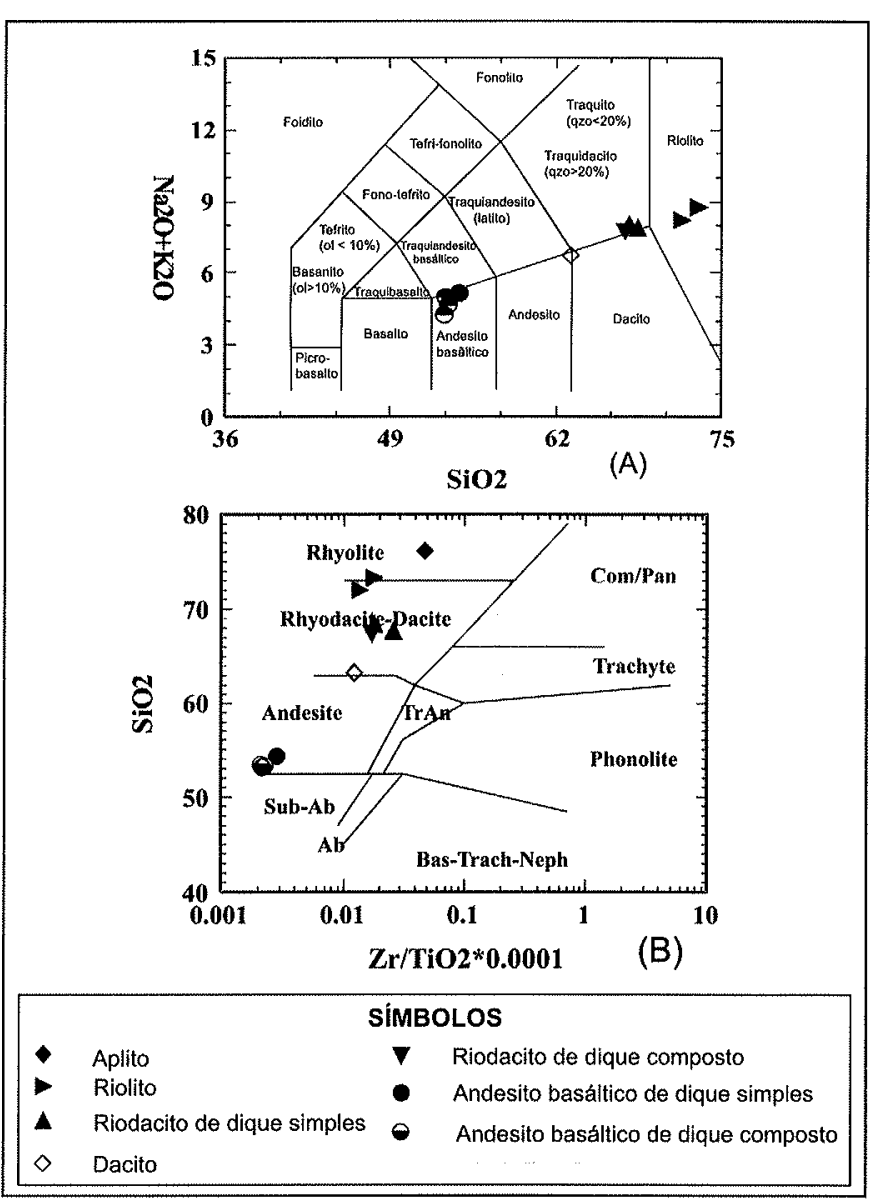

Figura 17-Diagramas de classificação química: (A) diagrama TAS (Le Bas et al, 1986); (B) diagrama $\mathrm{SiO}_{2}$ versus $\mathrm{Zr} / \mathrm{TiO}{ }_{2}$, de Winchester \& Floyd, (1977). 
Amostras de granito e de riolitos de dique mostram caráter metaluminoso (Fig. 22A), elevadas razões $\mathrm{FeOt} /(\mathrm{FeOt}+\mathrm{MgO}$ ) entre 0,84 e 0,90 (Fig. 22B) e índices de alcalinidade também elevados, transicionais entre o campo alcalino e cálcico-alcalino (Fig. 22C). Essas características evidenciam o caráter alcalino do granito e diques de riolito/aplito associados.

Riodacitos de diques compostos e de diques simples/corpos hipabissais, apresentam, também caráter metaluminoso (Fig. $22 \mathrm{~A})$, razões $\mathrm{Fet}(\mathrm{FeOt}+\mathrm{MgO})$, elevadas, porém pouco inferio- res às do granito/riolito (Fig. 22B) e índice de alcalinidade também pouco inferiores (Fig. 22C). Apesar dessas características que as colocam muito próximas aos granitos/riolitos alcalinos, os riodacitos, exibem teores em ferro bem mais altos, com FeOt entre 5,5 e $6,0 \%$, contra 2,8 a $3,4 \%$ dos granitos/riolitos, em que pese serem pouco menos diferenciados que esses. Essa maior concentração em ferro faz com que os riodacitos apresentem fases minerais férricas como pigeonita e assumam caráter toleítico, apesar do elevado teor em álcalis e de concentrações em
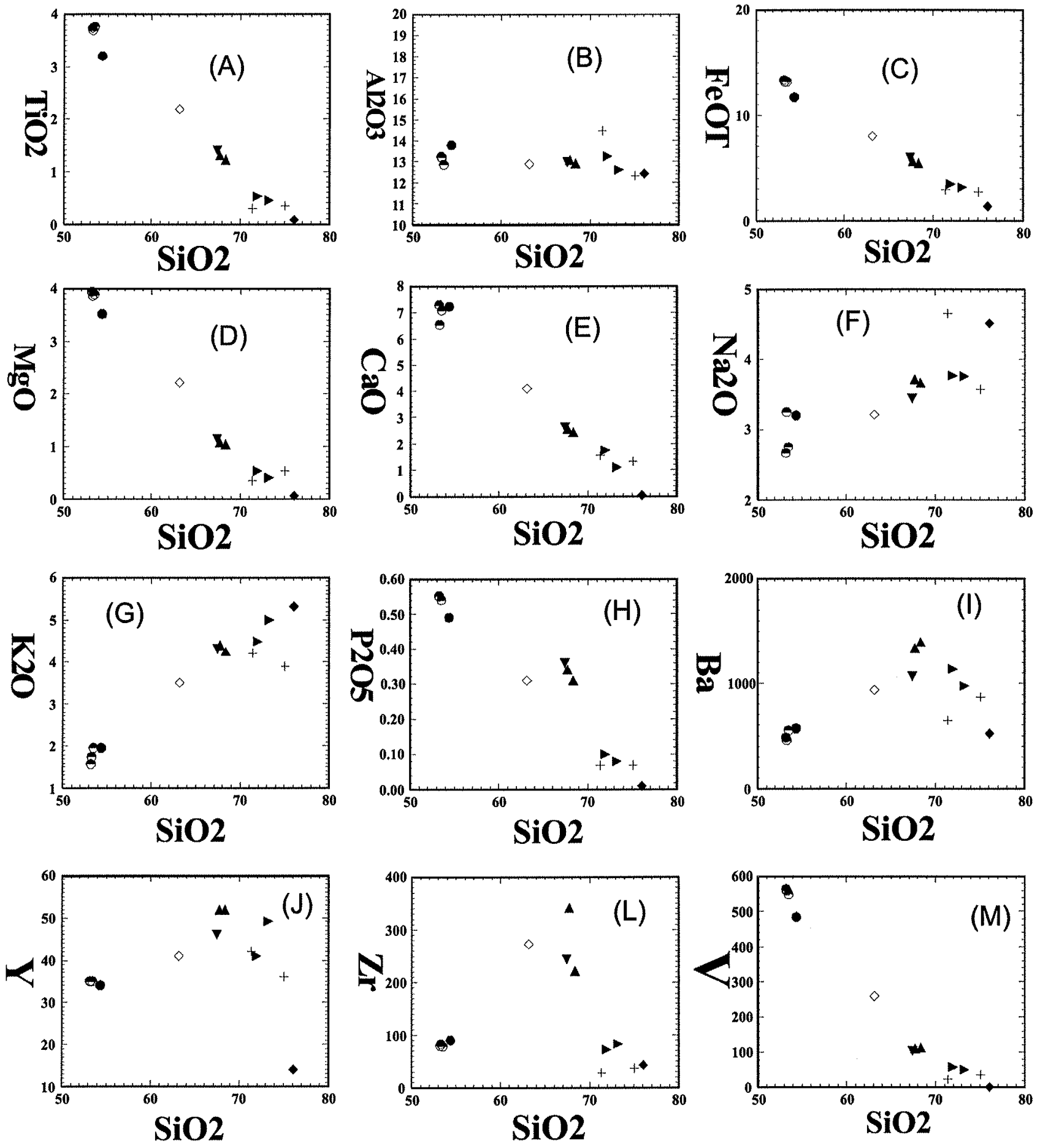

Figura 18 - Diagramas de variação para diversos óxidos (expressos em wt\%) e elementos traço (expressos em ppm). Símbolos: cruzes = granitos; demais simbolos, como na Fig. 17. 


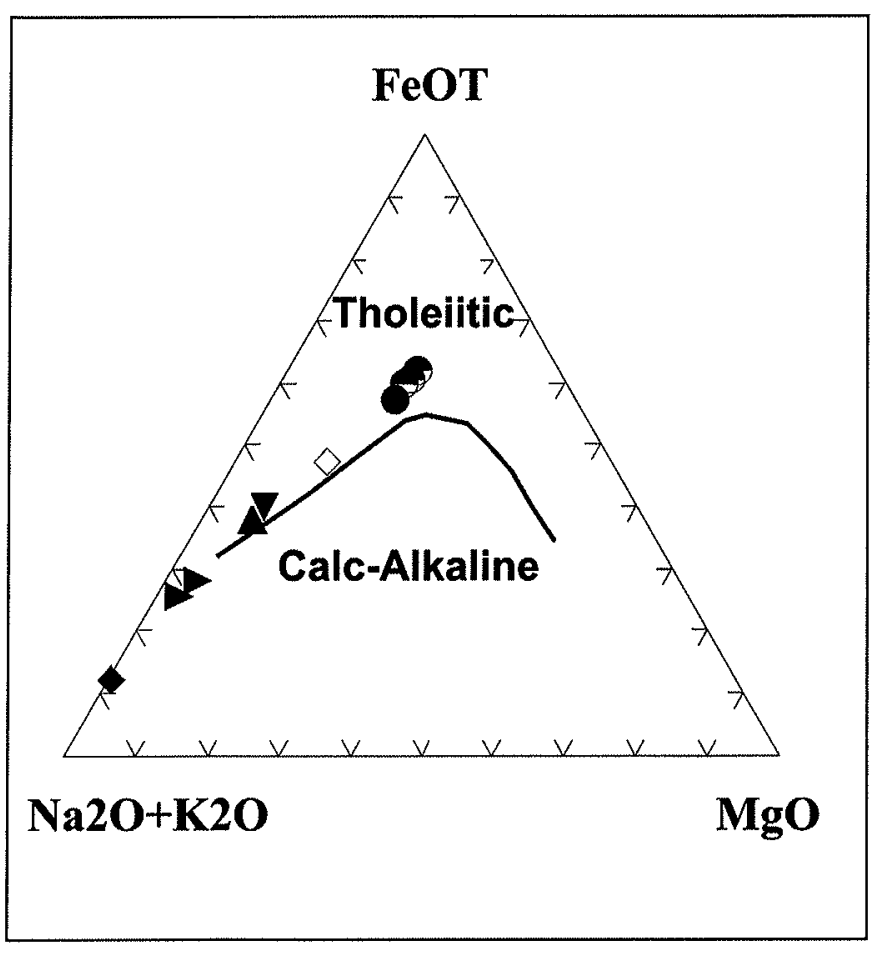

Figura 19 - Diagrama AFM, ambos de Irvine \& Baragar (1971). Mesmos símbolos da figura 22.

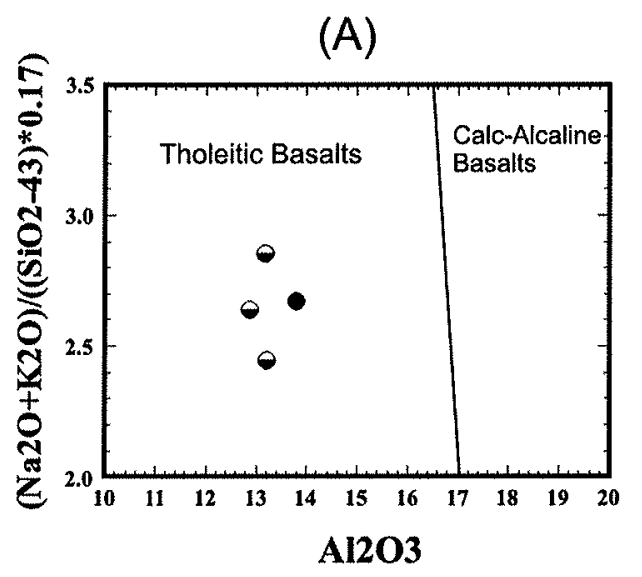

(B)

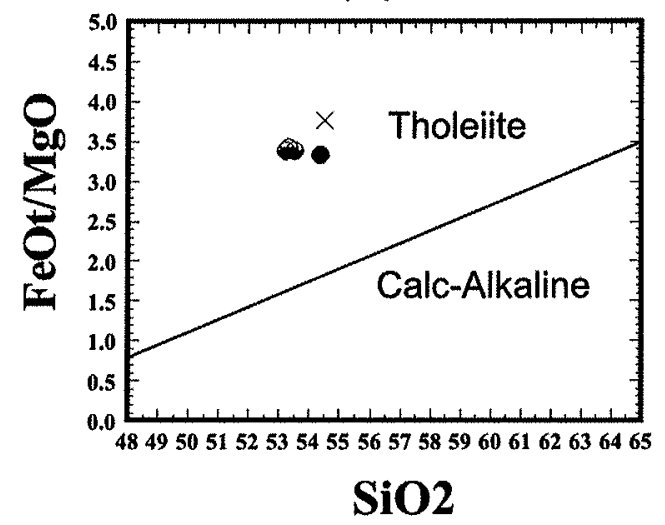

Figura 20-(A) Andesitos basálticos no campo de basaltos toleiticos do diagrama $\mathrm{IA}=\left(\mathrm{Na}_{2} \mathrm{O}+\mathrm{K}_{2} \mathrm{O}\right) /\left(\mathrm{SiO}_{2}-43\right) \times 0,17$ versus $\mathrm{SiO}_{2}$; (B) mesmas amostras no campo toleitico do diagrama $\mathrm{FeOt} / \mathrm{MgO}$ versus $\mathrm{SiO}_{2}$. elementos incompatíveis como $\mathrm{Ba}$ e $\mathrm{Zr}$ maiores do que os granitos/riolitos (Figs. 18I, 18L e 22D).

Os padrões de elementos terras raras, dos riodacitos toleíticos são diferentes dos granitos e riolitos alcalinos. Embora os riodacitos mostrem índices de diferenciação (teores em $\mathrm{SiO}_{2}$ ) mais baixos do que os dos riolitos, os primeiros mostram-se discretamente mais enriquecidos em ETRL e ETRP e não exibem a acentuada anomalia negativa de Eu que ocorre no granito e riolitos (Figs. 23A e 23D). Já o granito difere dos riolitos de dique por mostrar-se mais enriquecido em ETRL e empobrecido em ETRP (Fig. 23D) e com razões La/Lu mais elevadas: isso pode ser reflexo do índice diferenciação pouco mais elevado do granito.

Spindergrams normatizados por condrito, modelo de Sun (1980), aplicados para os riodacitos e granito/riolitos de dique (Figs. 23B e 23E) mostram padrões semelhantes, com anomalias negativas de $\mathrm{Sr}, \mathrm{P}$ e Ti mais acentuadas nos granito/riolitos. Esses diagramas diferenciam-se quanto ao Ta que mostra proeminente anomalia negativa para os granito/riolitos (Fig. 23E), o que não acontece para os riodacitos (Fig. 23B).

Nas Figs. 23C e 23F são apresentados os spidergrams para riodacitos e granito/riolitos, segundo o modelo de Pearce (1983), apontado por diversos autores como o mais apropriado para a comparação de rochas com índice de diferenciação distinto (Wilson, 1989). Comparando-se esses diagramas, observa-se que apresentam padrões semelhantes, embora para os granito/riolitos, haja anomalias negativas mais proeminentes em $\mathrm{P}, \mathrm{Ti}, \mathrm{Zr}$ e, novamente, uma bem marcada anomalia negativa em $\mathrm{Ta}$, que não está presente no spidergram dos riodacitos. Essa anomalia é a principal diferença entre os dois grupos de rochas e pode ter sido causada tanto por processos de contaminação crustal dos granito/riolitos como por processos de retenção desse elemento na fonte, durante a fusão parcial (Wilson, 1989).

Na Fig. 24A observa-se que os riodacitos têm uma assinatura semelhante a dos andesitos basálticos, embora sejam mais enriquecidos em ETR, Já os granito/riolitos exibem uma assinatura diferente, com forte anomalia negativa de Eu.

$\mathrm{Na}$ Fig. 24B, os granito/riolitos diferenciam-se dos riodacitos pelas anomalias negativas de $\mathrm{Ba}$ e Ta e pelas mais acentuadas anomalias negativas de $\mathrm{P}, \mathrm{Zr}$ e Ti. Os andesitos basálticos, por sua vez, mostram uma assinatura semelhante a dos riodacitos.

\section{MODELAMENTO GEOQUÍMICO}

Modelamento de cristalização fracionada Nos diques compostos, as bordas são de andesito basáltico e o centro de riodacito, por vezes com enclaves arredondados de andesito basáltico. Essas feições sugerem processos de mistura magmática entre eles. Geoquimicamente, ambos os litotipos são de filiação toleítica e apresentam padrões de ETR e de elementos traço incompatíveis que sugerem que o riodacito pode ter sido derivado do andesito basáltico por cristalização fracionada, antes da mistura magmática entre eles. Para testar essa hipótese, foi elaborado um modelamento geoquímico para cristalização fracionada entre esses dois termos (balanço de massa por regressão linear) utilizando-se o programa Gênesis, de Teixeira (1997). Os resultados, para elementos maiores, são apresentados na Figura 25.

Nesse modelamento, foi utilizado como composição inicial, a amostra de andesito basáltico da borda de dique composto (amostra DGR-18f) e como composição final, a amostra de riodacito do centro do mesmo dique composto (amostra DGR$18 \mathrm{~g}$ ). A partir da composição inicial, estimou-se o fracionamento dos minerais andesina, edenita, augita, magnetita e ilmenita, cujas composições químicas haviam sido obtidas por microssonda eletrônica. A composição final foi alcançada com o fracionamento de $61,04 \%$ desses minerais (Figura 25). Os resultados, que levam em conta a química mineral das fases sólidas 
(A)

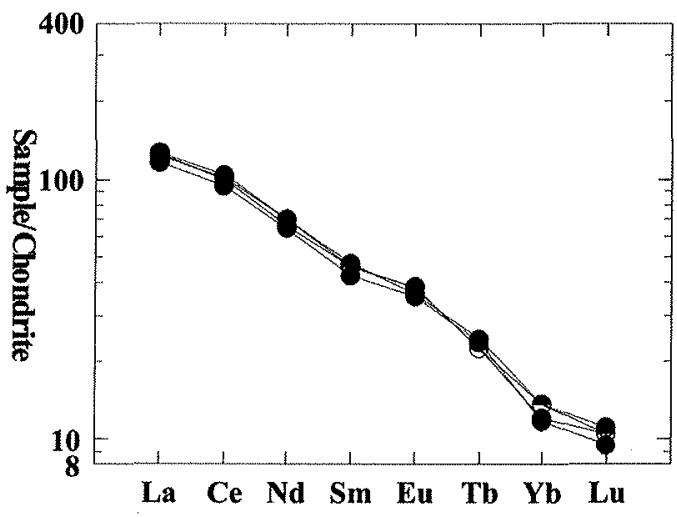

(C)

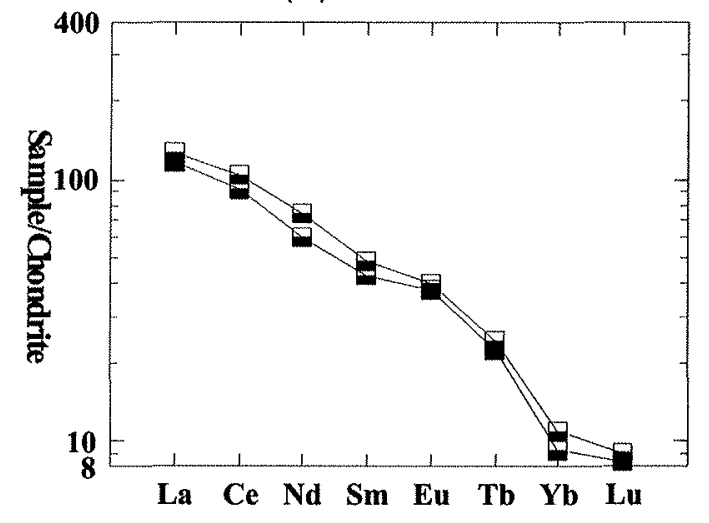

(B)

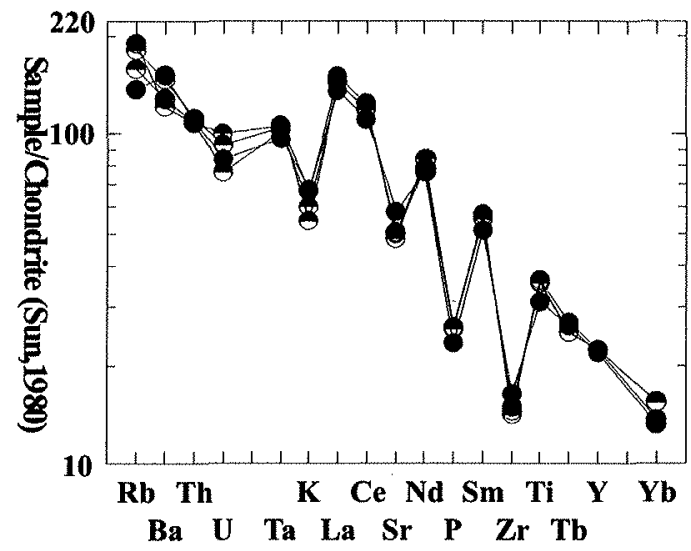

(D)

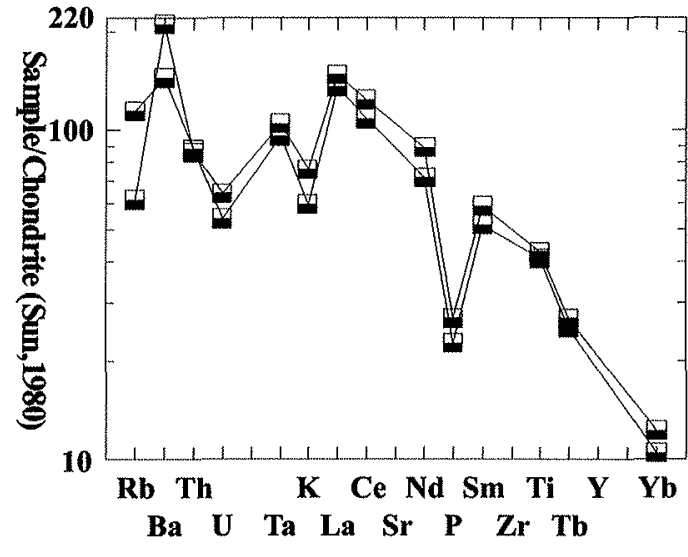

Figura 21 - (A) Diagrama de ETR para andesitos basálticos: (B) Spidergram segundo o modelo de Sun (1980) para andesitos basálticos; (C) Diagrama de ETR amostras de diabásios do Enxame de Diques Florianópolis na Ilha de Santa Catarina; (D) Spidergram de Sun (1980) para amostras de diabásios do Enxame de Diques Florianópolis na Ilha de Santa Catarina.

fracionadas (Cs) e a composição dos líquidos inicial e final (Co e Cf) mostraram um grau de congruência satisfatório, com uma soma do quadrado dos resíduos da regressão linear de 0,547, sustentando a hipótese de que os riodacitos toleíticos podem ter sido originados por cristalização fracionada a partir de andesitos basálticos de alto $K$.

Para o modelamento de cristalização fracionada de elementos traços, utilizou-se o módulo Traços do Programa Gênesis. Foi utilizada a mesma composição inicial (andesito basáltico) e as mesmas proporções de minerais fracionados calculadas na etapa anterior, Foram utilizados os coeficientes de partição (Kd) por dePaolo (1981). Os resultados desse teste são apresentados na Figura 26.

Os dados dessa tabela foram transpostos para os diagramas da Fig. 27, no sentido de facilitar a visualização. Na Fig. 27A é apresentado o diagrama de ETR, com o líquido inicial (andesito basáltico da borda básica do dique), as diversas proporções de fracionamento do líquido estão indicadas pelos valores 0,20 , $0,40,0,60$ e 0,80 . Uma amostra de riodacito do centro do dique composto (amostra DGR-18g), inserida no diagrama para fins de comparação. Observa-se que essa amostra exibe assinatura de ETR correspondente a um fracionamento de entre 40 e $60 \%$ do líquido inicial.

Na Fig. 27B os dados da tabela da Fig 26 estão dispostos sob a forma de spidergram. Observa-se, novamente, que os elementos traços do riodacito de centro do dique composto (amostra DGR$18 \mathrm{~g}$ ) mostram distribuição compatível a cerca de $40 \%$ de fracio- namento do líquido inicial, coerente, portanto, ao fracionamento de sólidos de 61,04\% (Fig. 25), calculado na etapa anterior.

CONSIDERAÇÕES FINAIS A llha do Arvoredo é constituída dominantemente por rochas graníticas metaluminosas da série alcalina (Granito Arvoredo), de composição semelhante aos granitos alcalinos neoproterozóicos de Porto Belo (SC), caracterizados por Bitencourt (1996) e ao Granito Ilha, descrito originalmente por Scheibe \& Teixeira (1970) e caracterizado por Zanini et al. (1997).

Intrusivo às rochas graníticas, ocorre enxame de diques de andesito basáltico de idade cretácea, que compõem a porção norte do Enxame de Diques Florianópolis. A esses diques, estão associados riodacitos, que podem formar diques simples ou corpos hipabissais de geometria não bem definida, geralmente mais espessos que aqueles, ou ainda diques compostos, com bordas de andesito basáltico e a parte central de riodacito. Enclaves e microenclaves arredondados de andesito basáltico em riodadacito, associados às feições de diques compostos, mostram que parece haver uma relação de mistura entre os magmas formadores desses dois litotipos. Embora a composição dos enclaves seja dificilmente avaliável, devido a processos de interação enclave-encaixante, observou-se que a química mineral de augitas de microenclaves básicos em riodacito de dique composto corresponde a de augitas de andesitos basálticos, particularmente quanto aos teores em $\mathrm{MnO}$ (Fig. 8). Tanto os andesitos basálticos como os riodacitos são rochas toleíticas de alto $\mathrm{K}$, enriquecidas 
(A)

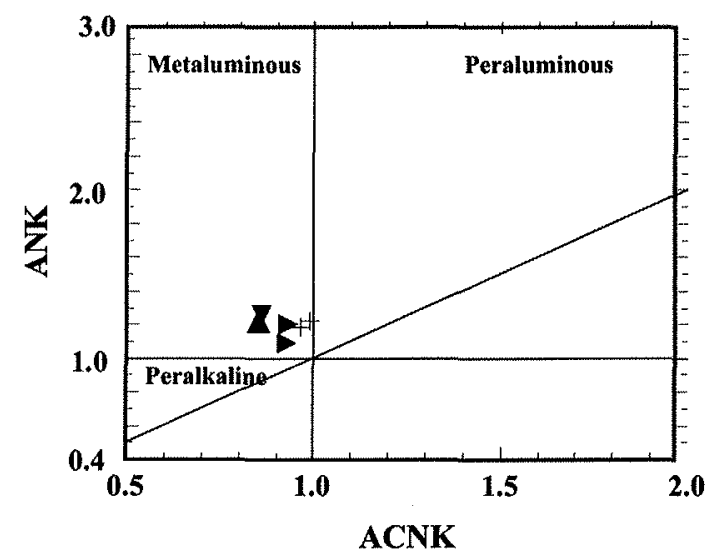

(C)

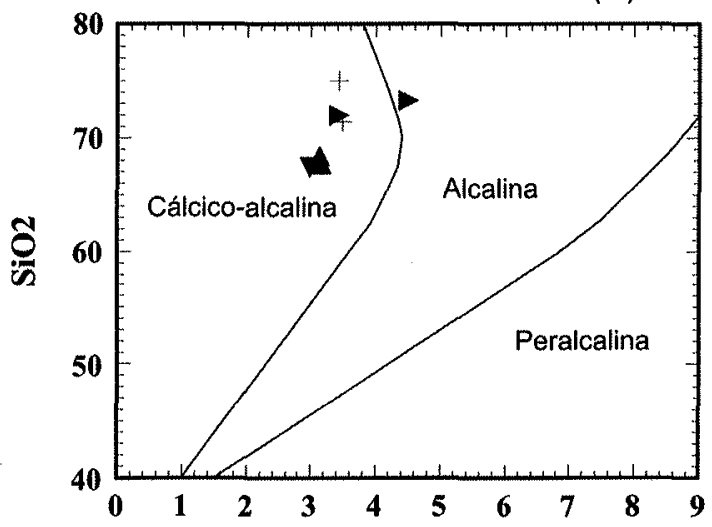

$(\mathrm{Al2O}+\mathrm{CaO}+\mathrm{Na2O}+\mathrm{K} 2 \mathrm{O}) /(\mathrm{Al} 2 \mathrm{O} 3+\mathrm{CaO}-\mathrm{Na} 2 \mathrm{O}-\mathrm{K} 2 \mathrm{O}$
(B)

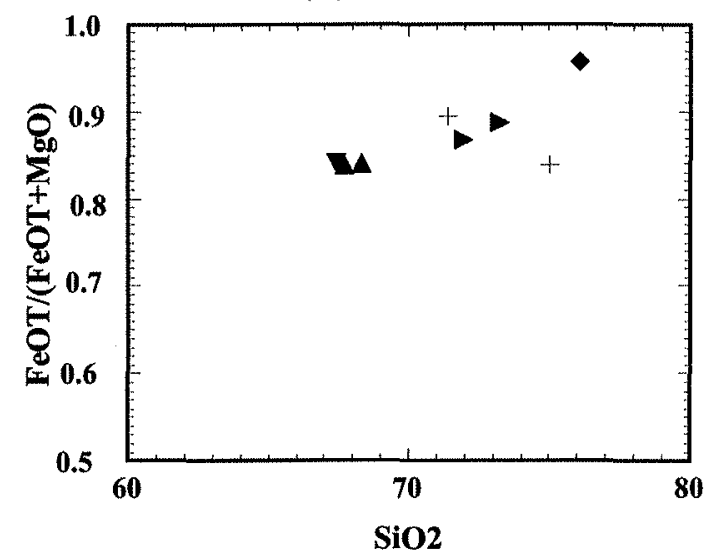

(D)

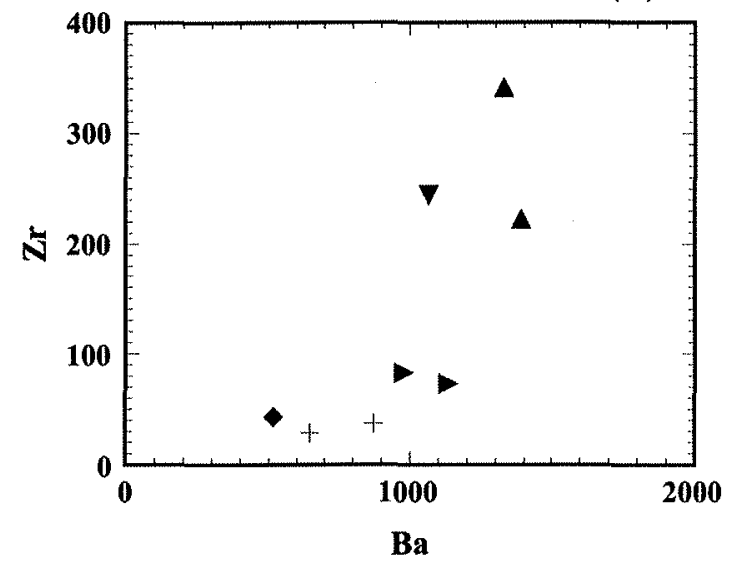

Figura 22 - (A) Diagrama de Maniar \& Piccoli (1989), utilizando os indices de aluminosidade de Shand: $\mathrm{ANK}=\mathrm{Al}_{2} \mathrm{O}_{3} /\left(\mathrm{Na} \mathrm{O}_{2}+\mathrm{K}_{2} \mathrm{O}\right)$ (molar); $\mathrm{ACNK}=\mathrm{Al}_{2} \mathrm{O}_{3} /\left(\mathrm{CaO}+\mathrm{Na}_{2} \mathrm{O}+\mathrm{K}_{2} \mathrm{O}\right.$ ) (molar). (B) Diagrama FeOt/(FeOt $+\mathrm{MgO}$ ) versus $\mathrm{SiO}_{2}$ (C) Diagrama de $\mathrm{SiO} \mathrm{O}_{2}$ versus $\mathrm{Razão}$ de Alcalinidade $=\left(\mathrm{Al}_{2} \mathrm{O}_{3}+\mathrm{CaO}+\mathrm{Na}_{2} \mathrm{O}+\mathrm{K}_{2} \mathrm{O}\right) / \mathrm{Al}_{2} \mathrm{O}_{3}+\mathrm{CaO}-\left(\mathrm{Na} \mathrm{O}_{2}+\mathrm{K}_{2} \mathrm{O}\right)$, de Wrigth (1969). (D) Diagrama $\mathrm{Zr}$ versus Ba. Simbolos: cruzes=granitos; demais simbolos como na Fig. 17.

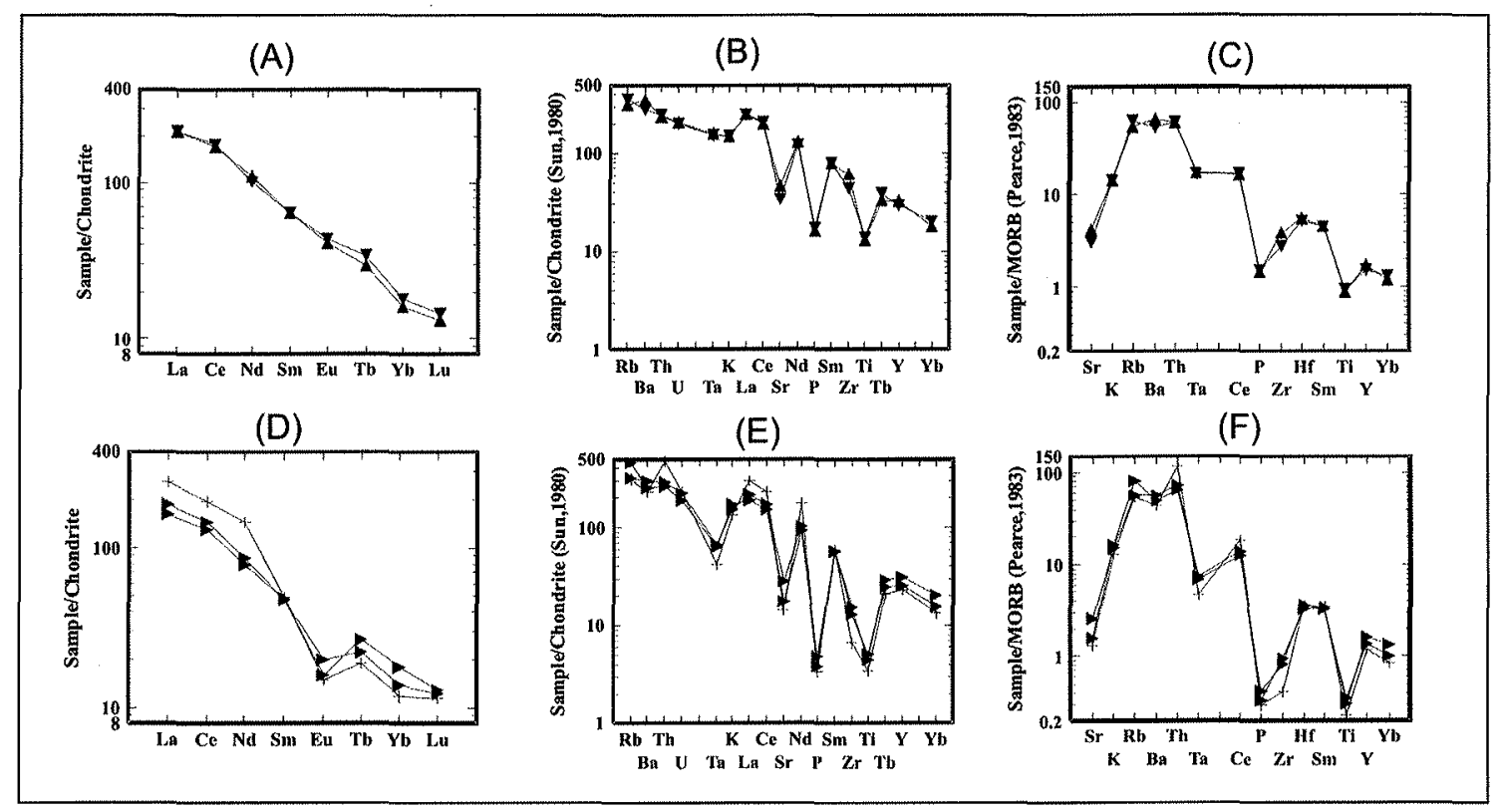

Figura 23 - (A) Diagrama de ETR para riodacitos de dique composto (triângulo c/vértice p/baixo) e de dique simples (triângulo c/ vértice p/cima); (B) spidergram de Sun (1980) para riodacitos de dique composto e de dique simples; (C) spidergram de Pearce (1983) para riodacitos de dique composto e de dique simples; (D) diagrama de ETR para granito (cruzes) e riolitos de dique (triângulos); (E) spidergram de Sun (1980) para granito e riolitos de dique; (F) spidergram de Pearce (1983) para granito e riolitos de dique. 
Tabela 4-Análises representativas de espinélios

\begin{tabular}{|c|c|c|c|c|}
\hline & \multicolumn{2}{|c|}{ Dique simples } & \multicolumn{2}{|c|}{ Dique composto } \\
\hline \begin{tabular}{|l|} 
Litotipo \\
\end{tabular} & And,Basált & Riodacito & Riodacito & And,Basált \\
\hline Posição & banda & centro & grão c/lam & grão c/lam \\
\hline Análise & $11 \mathrm{c} 4 \mathrm{p} 4$ & 63FP2A & $18 \mathrm{E} 4 \mathrm{P5}$ & $18 \mathrm{fc} 2 \mathrm{p5}$ \\
\hline SiO2 & 0,146 & 0,064 & 0,303 & 0,045 \\
\hline TiO2 & 0,606 & 12,42 & 13,076 & 1,225 \\
\hline A12O3 & 0,194 & 1,12 & 0,56 & 0,139 \\
\hline $\mathrm{FeO}$ & 31,498 & 41,242 & 41,553 & 32,275 \\
\hline $\mathrm{Fe} 2 \mathrm{O3}$ & 67,223 & 42,485 & 41,599 & 66,571 \\
\hline $\mathrm{Cr} 2 \mathrm{O3}$ & 0,058 & 0,021 & 0,002 & 0,151 \\
\hline $\mathrm{MnO}$ & 0 & 0,97 & 1,032 & 0 \\
\hline $\mathrm{MgO}$ & 0 & 0,014 & 0,017 & 0,028 \\
\hline $\mathrm{CaO}$ & 0,171 & 0,017 & 0,033 & 0,084 \\
\hline $\mathrm{ZnO}$ & 0,024 & 0,596 & 0,008 & 0,073 \\
\hline Total & 99,92 & 98,95 & 98,18 & 100,59 \\
\hline \multicolumn{5}{|c|}{ Cátions com base em 4 oxigênios } \\
\hline $\mathrm{Si}$ & 0,006 & 0,002 & 0,012 & 0,002 \\
\hline Al & 0,009 & 0,05 & 0,025 & 0,006 \\
\hline Ti & 0,018 & 0,357 & 0,379 & 0,035 \\
\hline $\mathrm{Fe} 2$ & 1,013 & 1,319 & 1,338 & 1,031 \\
\hline Fe3 & 1,943 & 1,222 & 1,204 & 1,912 \\
\hline $\mathbf{C r}$ & 0,002 & 0,001 & 0 & 0,005 \\
\hline $\mathbf{M n}$ & 0 & 0,031 & 0,034 & 0 \\
\hline $\mathbf{M g}$ & 0 & 0,001 & 0,001 & 0,002 \\
\hline $\mathbf{C a}$ & 0,007 & 0,001 & 0,001 & 0,003 \\
\hline $\mathbf{Z n}$ & 0 & 0,02 & 0 & 0 \\
\hline Cations & 2,998 & 3,004 & 2,994 & 2,996 \\
\hline
\end{tabular}

Tabela 5 - Análises representativas de Ilmenitas

\begin{tabular}{|c|c|c|c|c|}
\hline \multirow[b]{2}{*}{ Litotipo } & \multicolumn{2}{|c|}{ Diques simples } & \multicolumn{2}{|c|}{ Diques compostos } \\
\hline & And.Basál & Riodacito & Riodacito & And.Basált \\
\hline Posição & lamela & lamela & porção & grão puro \\
\hline Análise & $11 \mathrm{c} 2 \mathrm{p} 3$ & 69G2P3 & 18G3P6 & $18 f \mathrm{c} 3 \mathrm{p3}$ \\
\hline $\mathrm{SiO2}$ & 0,049 & 0,011 & 0,023 & 0,002 \\
\hline TiO2 & 49.522 & 51.649 & 51.944 & 49.824 \\
\hline Al2O3 & 0,015 & 0,018 & 0,001 & 0,008 \\
\hline $\mathrm{FeO}$ & 42.818 & 41.911 & 42,31 & 42.138 \\
\hline $\mathrm{Fe} 2 \mathrm{O3}$ & 5,17 & 2.291 & 1.651 & 5.417 \\
\hline $\mathrm{Cr} 2 \mathrm{O3}$ & 0,004 & 0,01 & 0 & 0,045 \\
\hline $\mathrm{MnO}$ & 1.526 & 4.431 & 4.343 & 2.309 \\
\hline $\mathrm{MgO}$ & 0,101 & 0,035 & 0 & 0,198 \\
\hline $\mathrm{CaO}$ & 0,512 & 0,07 & 0,049 & 0,126 \\
\hline Total & 99,72 & 100,43 & 100,32 & 100,07 \\
\hline \multicolumn{5}{|c|}{ Cátions com base em 3 oxigênios } \\
\hline$\overline{S i}$ & 0,001 & 0 & 0,001 & 0 \\
\hline$\overline{\mathbf{A l}}$ & 0 & 0,001 & 0 & 0 \\
\hline $\mathbf{T i}$ & 0,945 & 0,977 & 0,984 & 0,947 \\
\hline $\mathrm{Fe} 2$ & 0,908 & 0,882 & 0,891 & 0,89 \\
\hline Fe3 & 0,099 & 0,043 & 0,031 & 0,103 \\
\hline$\overline{\mathbf{C r}}$ & 0 & 0 & 0 & 0,001 \\
\hline Mn & 0,033 & 0,094 & 0,093 & 0,049 \\
\hline Mg & 0,004 & 0,001 & 0 & 0,007 \\
\hline $\mathrm{Ca}$ & 0,014 & 0,002 & 0,001 & 0,003 \\
\hline Cations & 2,004 & 2 & 2,001 & 2 \\
\hline$X$ il & 0,91302 & 0,88332 & 0,89145 & 0,89223 \\
\hline X hem & 0,04977 & 0,02153 & 0,01551 & 0,05163 \\
\hline$X$ py & 0,03318 & 0,09414 & 0,09305 & 0,04912 \\
\hline$X$ gk & 0,00402 & 0,00100 & 0,00000 & 0,00702 \\
\hline
\end{tabular}
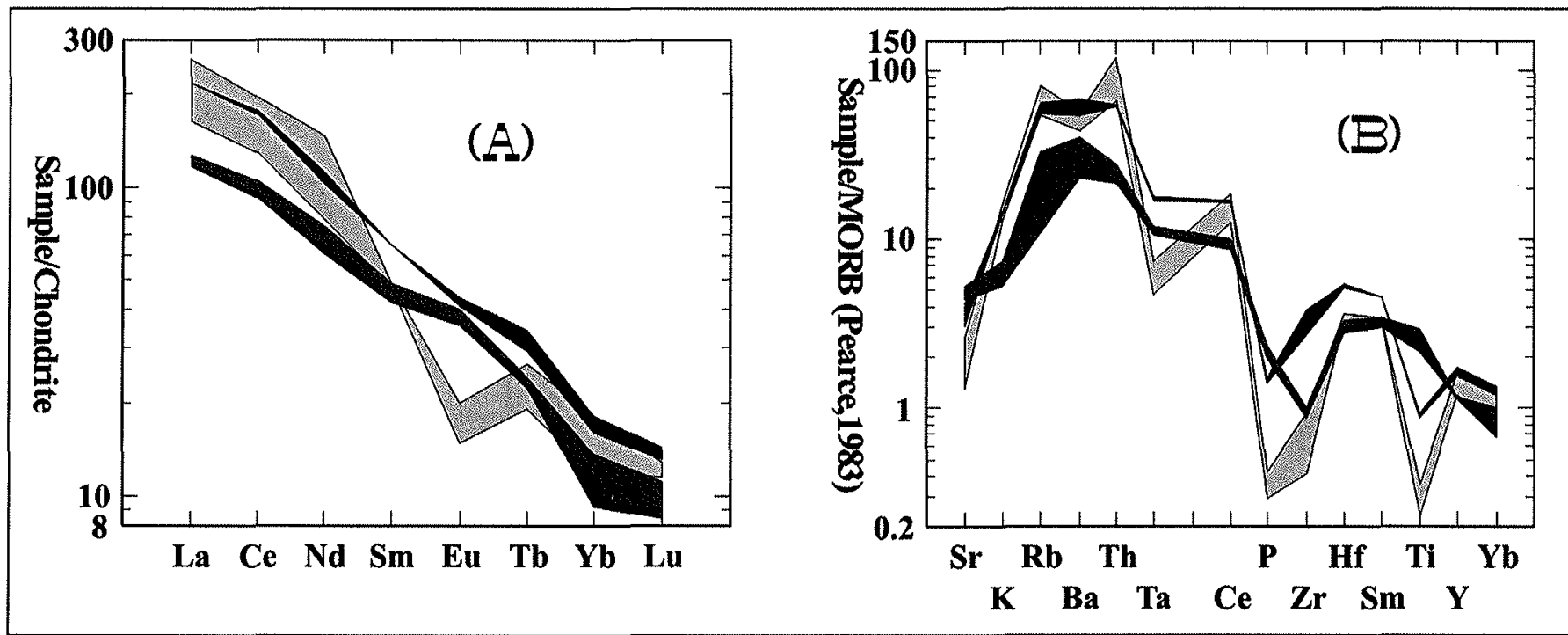

Figura 24 - (A) Diagrama de ETR, reunindo todos os litotipos discutidos, Áreas cinza-claro: granito e riolitos de dique; áreas pretas: riodacitos; áreas cinza-escuro: andesitos basálticos. (B) Spidergram segundo modelo de Pearce (1983) para os mesmos três grupos de litotipos.

em Ti, P e elementos traço incompatíveis. Os riodacitos exibem, muitas vezes, cristais de pigeonita, com bordas substituídas por anfibólio. A presença de pigeonita ratifica a filiação toleítica dos riodacitos, implicando em um enriquecimento em ferro mesmo nos termos ácidos. A pigeonita aponta, também, para uma condição magmática anidra nas fases iniciais de cristalização, que teria evoluído para uma condição mais hidratada, caracterizada pelas bordas de pigeonita substituídas por anfibólio. Essa hidra- 
Regressäo de Co-18f (Co) para Cf-18g (Cf).

1 - Soma dos quadrados dos residuos: 0.547

2 - Dados relativos às composiçőes de Co, Cf, Cs e fases minerais utilizadas:

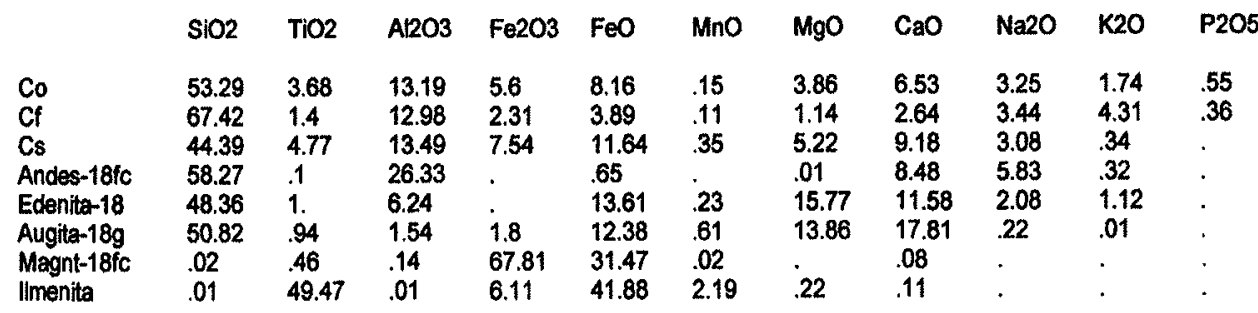

\section{3- Composiçăo modal de Cs:}

$\begin{array}{ll}\text { Andes-18fc } & 46.15 \% \\ \text { Edenita-18 } & 16.53 \% \\ \text { Augila-18g } & 18.70 \% \\ \text { Magnt-18fc } & 09.84 \% \\ \text { Ilmenita } & 08.77 \% \\ \text { (1-F) } \times 100= & 61.04 \%\end{array}$

\section{4 - Composiçăo dos liquidos (Ci) em funçăo de diferentes valores de $F$}

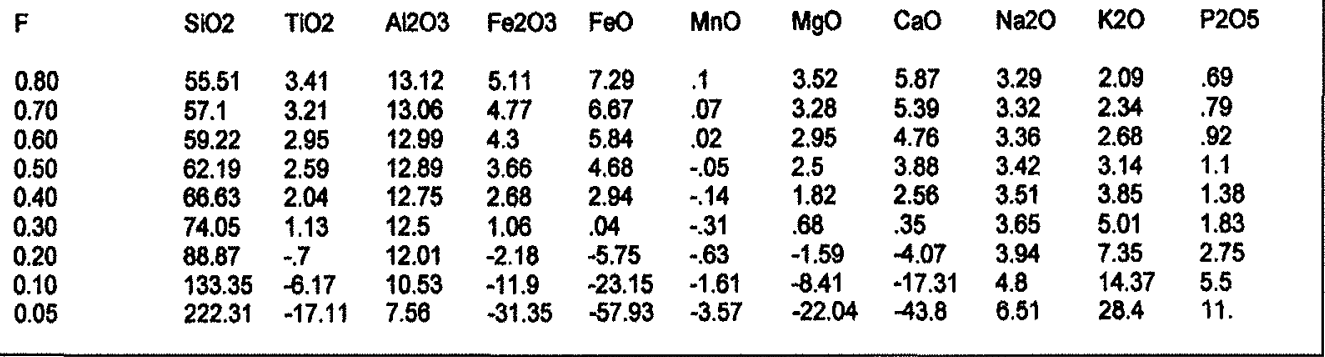

Figura 25 - Resultados modelamento geoquímico para cristalização fracionada em dique composto.

\section{Cristalizaçåo Fracionada em Equllibrio}

\section{1 - Composição modal do sólido (em \%):}

$\begin{array}{ll}\text { Plag. } & 46.15 \\ \text { Homblenda } & 16.53 \\ \text { cpx } & 18.70 \\ \text { Magnetita } & 9.84 \\ \text { Imenita } & 8.77\end{array}$

2 - Composiçio de Co e dos liquidos obtidos em funçăo de F:

\begin{tabular}{|c|c|c|c|c|c|c|c|c|c|c|}
\hline Elem. & Co & 0.80 & 0.70 & 0.60 & 0.50 & 0.40 & 0.30 & 0.20 & 0.10 & 0.05 \\
\hline $\begin{array}{l}\mathrm{Cr} \\
\mathrm{Ni} \\
\mathrm{Co} \\
\mathrm{V} \\
\mathrm{Rb} \\
\mathrm{Ba} \\
\mathrm{Sr} \\
\mathrm{Zr} \\
\mathrm{Y} \\
\mathrm{La} \\
\mathrm{Ce} \\
\mathrm{Nd} \\
\mathrm{Sm} \\
\mathrm{Eu} \\
\mathrm{Tb} \\
\mathrm{Yb} \\
\mathrm{Lu}\end{array}$ & $\begin{array}{l}6.00 \\
46.00 \\
285 \\
558 \\
66.00 \\
460 \\
548 \\
84.00 \\
35.00 \\
45.10 \\
97.00 \\
50.00 \\
10.60 \\
3.33 \\
1.30 \\
3.00 \\
.40\end{array}$ & $\begin{array}{l}4.60 \\
34.15 \\
228 \\
466 \\
81.09 \\
550 \\
547 \\
98.70 \\
37.66 \\
54.62 \\
113 \\
59.04 \\
12.36 \\
3.40 \\
1.47 \\
3.43 \\
.46\end{array}$ & $\begin{array}{l}4.11 \\
30.25 \\
207 \\
430 \\
91.55 \\
610 \\
547 \\
108 \\
39.14 \\
61.07 \\
122 \\
64.92 \\
13.47 \\
3.43 \\
1.56 \\
3.70 \\
.49\end{array}$ & $\begin{array}{l}3.72 \\
27.15 \\
190 \\
399 \\
105 \\
685 \\
547 \\
120 \\
40.75 \\
69.25 \\
134 \\
72.09 \\
14.81 \\
3.47 \\
1.68 \\
4.01 \\
.54\end{array}$ & $\begin{array}{l}3.40 \\
24.63 \\
175 \\
373 \\
123 \\
780 \\
547 \\
134 \\
42.50 \\
79.95 \\
148 \\
81.03 \\
16.45 \\
3.51 \\
1.81 \\
4.38 \\
.58\end{array}$ & $\begin{array}{l}3.13 \\
22.54 \\
163 \\
350 \\
149 \\
906 \\
546 \\
152 \\
44.40 \\
94.56 \\
166 \\
92.52 \\
18.49 \\
3.54 \\
1.96 \\
4.83 \\
.64\end{array}$ & $\begin{array}{l}2.90 \\
20.77 \\
152 \\
329 \\
189 \\
1081 \\
546 \\
175 \\
46.48 \\
116 \\
188 \\
108 \\
21.11 \\
3.58 \\
2.15 \\
5.37 \\
.72\end{array}$ & $\begin{array}{l}2.70 \\
19.26 \\
142 \\
311 \\
258 \\
1339 \\
546 \\
208 \\
48.77 \\
149 \\
217 \\
129 \\
24.59 \\
3.62 \\
2.37 \\
6.06 \\
.81\end{array}$ & $\begin{array}{l}2.53 \\
17.96 \\
134 \\
295 \\
408 \\
1759 \\
546 \\
255 \\
51.29 \\
209 \\
256 \\
161 \\
29.45 \\
3.66 \\
2.64 \\
6.94 \\
.93\end{array}$ & $\begin{array}{l}2.45 \\
17.37 \\
130 \\
287 \\
568 \\
2087 \\
545 \\
287 \\
52.65 \\
262 \\
282 \\
184 \\
32.67 \\
3.68 \\
2.80 \\
7.49 \\
1.00\end{array}$ \\
\hline
\end{tabular}

Figura 26-Resultados de modelamento geoquímico de cristalização fracionada para elementos traços, obtidos com a utilização do programa Gênesis (Teixeira, 1997). 
Tabela 6 - Amostras representativas de litotipos da Ilha do Arvoredo

\begin{tabular}{|c|c|c|c|c|c|c|c|c|c|}
\hline \multirow{2}{*}{\begin{tabular}{|l} 
Contexto \\
Litotipo
\end{tabular}} & \multirow{2}{*}{$\begin{array}{l}\text { Plúton } \\
\text { Granito }\end{array}$} & \multirow{2}{*}{$\begin{array}{l}\text { Dique } \\
\text { Riolito }\end{array}$} & \multirow{2}{*}{\begin{tabular}{|l|} 
Dique \\
And.Basált \\
\end{tabular}} & \multicolumn{2}{|c|}{ Dique composto } & \multicolumn{2}{|c|}{ Diques ácidos-intem. } & \multicolumn{2}{|c|}{$\begin{array}{c}\text { Diques } \\
\text { Enx.Florianópolis }\end{array}$} \\
\hline & & & & And.Basált & Riodacito & Riodacito & Dacito & Diabásio & Diabásio \\
\hline Amostra & DGR1 & DGR7 & DGR10 & DGR18a & DGR18g & DGR3 & DGRDb & PM48a & PM48b \\
\hline $\mathrm{SiO} 2$ & 75,02 & 73,22 & 54,37 & 53,48 & 67,41 & 67,7 & 63,18 & 50,51 & 50,94 \\
\hline TiO2 & 0,35 & 0,46 & 3,2 & 3,76 & 1,4 & 1,31 & 2,18 & 4,41 & 4,21 \\
\hline $\mathrm{Al2O3}$ & 12,33 & 12,62 & 13,81 & 12,86 & 12,98 & 13,1 & 12,91 & 12,77 & 13,11 \\
\hline $\mathrm{Fe} 2 \mathrm{O3}$ & 1,18 & 1,35 & 4 & 3,5 & 2,31 & 2,15 & 1,91 & 13,5 & 13,41 \\
\hline $\mathrm{FeO}$ & 1,7 & 1,93 & 8,11 & 10,02 & 3,89 & 3,67 & 6,34 & & \\
\hline FeOT & 2,76 & 3,14 & 11,71 & 13,17 & 5,97 & 5,6 & 8,06 & 13,5 & 13,41 \\
\hline $\mathrm{MnO}$ & 0,05 & 0,06 & 0,15 & 0,16 & 0,11 & 0 & 0,14 & 0,174 & 0,174 \\
\hline MgO & 0,53 & 0,4 & 3,51 & 3,89 & 1,14 & 1,07 & 2,21 & 4,31 & 4,3 \\
\hline $\mathrm{CaO}$ & 1,31 & 1,13 & 7,21 & 7,09 & 2,64 & 2,56 & 4,09 & 7,85 & 8,17 \\
\hline $\mathrm{Na2O}$ & 3,57 & 3,75 & 3,21 & 2,75 & 3,44 & 3,71 & 3,22 & 3,11 & 2,9 \\
\hline $\mathrm{K2O}$ & 3,89 & 5 & 1,96 & 1,95 & 4,31 & 4,38 & 3,5 & 2,2 & 1,72 \\
\hline P2O5 & 0,07 & 0,08 & 0,49 & 0,54 & 0,36 & 0,34 & 0,31 & 0,566 & 0,472 \\
\hline LOI & 1,03 & 0,82 & 1,78 & 1,4 & 0,89 & 0,69 & 0,93 & 0,6 & 0,6 \\
\hline Total & 101,03 & 100,82 & \begin{tabular}{|l|l}
101,8 \\
\end{tabular} & 101,4 & 100,88 & 100,68 & 100,92 & 100 & 100,01 \\
\hline $\mathbf{B a}$ & 870 & 978 & 572 & 554 & 1068 & 1331 & 940 & 797 & 547 \\
\hline $\mathbf{R b}$ & 109 & 160 & 48 & 63 & 126 & 110 & 69 & 21,5 & 40 \\
\hline $\mathrm{Sr}$ & 158 & 191 & 642 & 529 & 371 & 502 & 440 & & \\
\hline Cs & 2 & 2,3 & 1,9 & 5,84 & 1,35 & 2,2 & 2,57 & 1,5 & 0,81 \\
\hline $\mathbf{T a}$ & 0,85 & 1,25 & 1,93 & 2,1 & 3,06 & 3,2 & 2,84 & 2,1 & 1,91 \\
\hline Hf & 8,5 & 8 & 6,7 & 7,5 & 12,3 & 13 & 8,8 & 7,9 & 7,2 \\
\hline $\mathbf{Z r}$ & 37 & 84 & 91 & 79 & 244 & 341 & 273 & & \\
\hline $\mathbf{Y}$ & 36 & 49 & 34 & 35 & 46 & 52 & 41 & & \\
\hline Th & 23,6 & 13,1 & 5,5 & 5,6 & 12,4 & 12,1 & 7,4 & 4,3 & 4,4 \\
\hline $\mathbf{U}$ & 3 & 2,5 & 1,09 & 1,2 & 2,6 & 2,7 & 1,8 & 0,84 & 0,7 \\
\hline $\mathrm{Cr}$ & 1 & 1 & 21 & 9 & 0 & 6 & 15 & 50 & 42 \\
\hline $\mathrm{Ni}$ & 0 & 0 & 46 & 51 & 0 & 6 & 14 & 0 & 0 \\
\hline Co & 255 & 301 & 469 & 249 & 171 & 246 & 243 & 37 & 37 \\
\hline Sc & 6,1 & 7,3 & 23 & 28,1 & 13,5 & 11,9 & 20,3 & 22,8 & 22,5 \\
\hline $\mathrm{V}$ & 35 & 50 & 484 & 549 & 103 & 110 & 259 & 0 & 0 \\
\hline $\mathrm{Cu}$ & 1 & 13 & 149 & 170 & 10 & 9 & 29 & 0 & 0 \\
\hline $\mathbf{Z n}$ & 66 & 69 & 126 & 154 & 122 & 100 & 121 & 93 & 108 \\
\hline $\mathbf{B e}$ & 2,04 & 3,01 & 2,03 & 2,03 & 3,05 & 4,01 & 3,03 & & \\
\hline $\mathbf{L a}$ & 95 & 60,1 & 42,5 & 46,8 & 79,4 & 79,3 & 50,9 & 46,3 & 42,7 \\
\hline $\mathrm{Ce}$ & 187 & 124 & 90 & 100 & 169 & 164 & 108 & 100 & 88 \\
\hline Nd & 104 & 56 & 46 & 50 & 73 & 79 & 50 & 53 & 43 \\
\hline $\mathbf{S m}$ & 11,3 & 11,1 & 9,8 & 10,9 & 15 & 15 & 10,2 & 11,3 & 9,9 \\
\hline $\mathbf{E u}$ & 1,29 & 1,38 & 3,1 & 3,17 & 3,8 & 3,6 & 2,88 & 3,5 & 3,3 \\
\hline Tb & 1,11 & 1,55 & 1,36 & 1,4 & 2 & 1,71 & 1,2 & 1,4 & 1,3 \\
\hline $\mathbf{Y b}$ & 2,9 & 4,5 & 2,9 & 3,4 & 4,5 & 4 & 3,1 & 2,7 & 2,3 \\
\hline $\mathbf{L u}$ & 0,44 & 0,49 & 0,36 & 0,42 & 0,55 & 0,5 & 0,4 & 0,34 & 0,32 \\
\hline
\end{tabular}




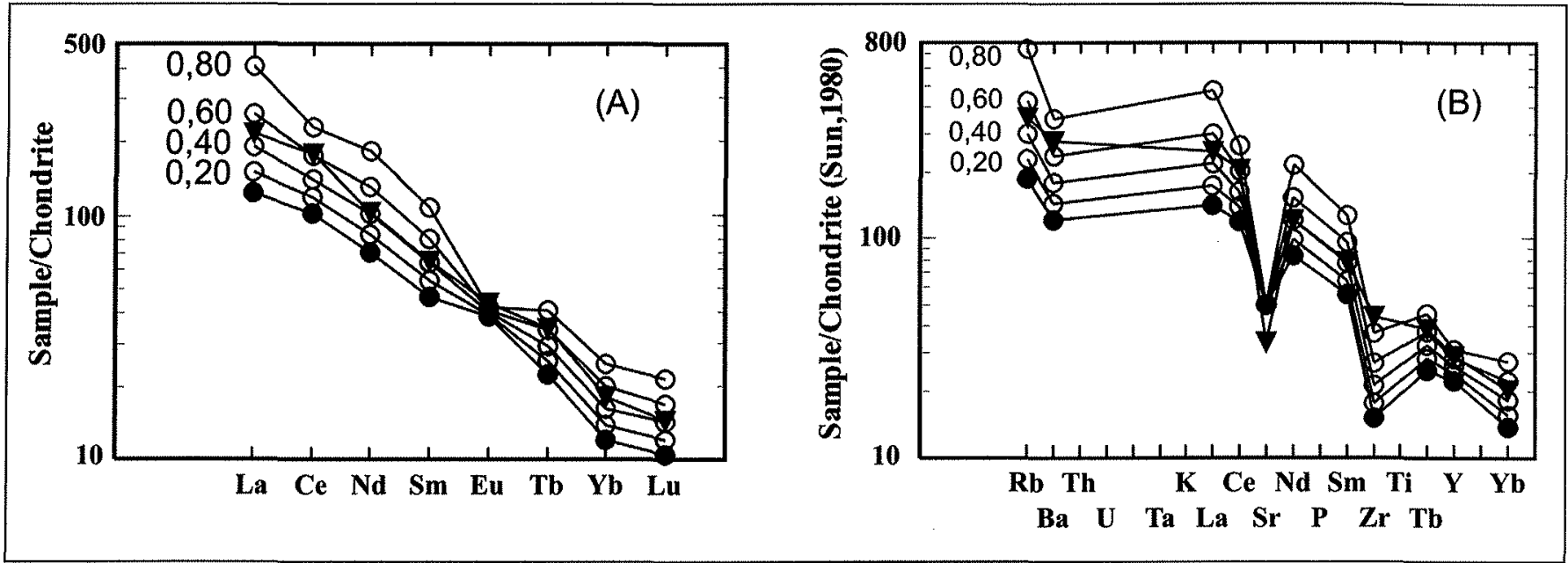

Figura 27 - (A) Diagrama de ETR mostrando graficamente o resultado do modelamento geoquímico para fracionamento magmático. Símbolos: círculos preenchidos = líquido de composição inicial - andesito basáltico da borda de dique composto (amostra DGR-18f); círculos vazios = diversas proporções de fracionamento do líquido inicial; triângulos = amostra de riodacito do centro do dique composto (DGR-18g) inserida no diagrama para fins de comparação. (B) Spidergram segundo modelo de Sun (1980) mostrando graficamente o resultado do modelamento de elementos traços para cristalização fracionada. Mesmos símbolos de (A).

tação pode ser reflexo do processo de mistura magmática entre andesitos basálticos e riodacitos.

Zonações cíclicas nos plagioclásios e de zonações pouco comuns em piroxênios, que exibem, por vezes, núcleo de pigeonita manteado por bordas augíticas apresentam-se como outras evidências mineralógicas do processo de mistura magmática.

A ocorrência de magnetita titanífera $\left(\mathrm{Usp}_{8-38}\right)$ em riodacitos, o que não é usual em rochas ácidas, indica condição da baixa fugacidade de oxigênio, pelo menos nas fases iniciais de cristalização, sendo mais uma evidência do caráter toleítico dessas rochas.

Modelamento geoquímico de fracionamento magmático mostrou que os riodacitos podem ter sido derivados dos ande- sitos basálticos por $61,04 \%$ de cristalização fracionada dos minerais andesina $(45,15 \%)$, edenita $(16,53 \%)$, augita $(18,70 \%)$, magnetita $(9,84 \%)$ e ilmenita $(6,77 \%)$. A mistura magmática, entre os termos ácidos e intermediários, bem evidenciada nos diques compostos, teria operado após o fracionamento.

Termos ácidos como riodacitos são, portanto, constituintes importantes do Enxame de Diques Florianópolis na Ilha do Arvoredo, predominando sobre os termos básicos em área de ocorrência (Fig. 1).

Riolitos mostram significativas diferenças geoquímicas com os riodacitos que permitem diferenciá-los e correlacionar os riolitos ao Granito Arvoredo.

\section{Referências}

Bitencourt M.F., Nardi L.V.S.,Hackspacher P.C. 1989. Diques Compostos da Enseada dos Zimbros, Região de Porto Belo, SC. In: Congr. Bras. Geoq., 2, Rio de Janeiro, Bol. de Resumos Expandidos, 1:177-181.

Bitencourt M.F. \& Nardi L.V.S. 1993. Late to pós-collisional brasiliano magmatism in southernmost Brazil An. Acad. Brás. Ci. 65:3-16.

Bitencourt M.F. 1996. Granitóides Sintectônicos da Região de Porto Belo, SC: uma Abordagem Petrológica e Estrutural do Magmatismo em Zonas de Cisalhamento. Tese de Doutorado. Instituto de Geociências, Universidade Federal do Rio Grande do Sul, 255p.

DePaolo D. J. 1981. Trace element and isotopic effects of combined wallrock assimilation and crystallization. Earth and Planetary Science Letters, 53: 189-202.

Didier J. \& Barbarin B. 1991 (eds.). Enclaves and Graniie Petrology. Elsevier, New York, 545 pp.

Frost B.R- \& Lindsley D.H. 1991. Occurrence ofiron-titanium oxides in igneous rocks. In: Lindsley D. H- (ed.) Oxide Minerais Pefrologic and Magnetic Significance. Reviews in Mineralogy, 25:433-462.

Fuhrman M.L., Frost B.R. \& Lindsley D.H. 1988. Crystalization condí- tions of the Sybille Monzosyenite, Laramie Anorthosite Complex, Wyoming. J. Petrol., 29:699-729.

Haggerty S.E. 1991. Oxide Textures - A Mini-Atlas. In: Lindsley d. H. (ed.) Oxide Minerais Petrologic and Magnetic Significance. Reviews in Mineralogy, 25:128-218

Irvine T.N. \& Baragar W.R.A. 1971. A guide to chemical classification of the common volcanic rocks. Can. J. Earth Sci., 8: 523-548,

Leake B.E., Wooley, A.R., Arps, C.E.S., Birch, W.D., Gilbert, M.C., Grice, J.D., Hawthome, F.C., Kato A., Kisch H.J., Krivovichev V. G., Linthout K-, Laírd, J., Mandarino J.A., Maresh W. V., Nickel E.H., Rock N.M.S., Schuniacher J.C., Smith D.C., Stephenson N.C.N., Ungaretti L., Whittaker, E.J.W., Youzhi, G. 1997. Nomenclature of amphiboles: report of sub commitee on amphiboles of the Intemational Mineralogical Association, commission on new minerals and mineral names. Canadian Mineralogist, 35:219-246.

Le Bas M.J., Le Maitre R.W., Streckeisen A.,Zanettin B. 1986. A classification of volcanic rocks based on the total alcalis-silica diagram. J. Petrol., 27:745-750

Maniar P.D. \& Piccoli P.M. 1989. Tectonic discrimination of granitoids. Geological Society of America Bulletin, 101:635-643. 
Middlemost E.A. 1975. The basalt clan. Earth Sci. Rev., 11:337-364.

Miyashiro A. 1974. Volcanic rock series in island ares and active continental margins. Am. J. Sci., 274: 321-355.

Morimoto N. 1988. Nomenclature of pyroxenes. American Mineralogist, 73: 1123-1133.

Scheibe L.F. \& Teixeira V.H.1970. Mapa Topogeológico da Ilha de Santa Catarina. Porto Alegre. DNPM.(inédito).

Pearce J.A. 1983. Role ofthe sub-continental lithosphere in magma genesis at active continental margins. In: Hawkesworth, C.J. \& Nony M.J. (eds.) Continental Basalts and Mantle Xenoliths, Shiva Publishing Limited, pp.: 230-249.

Raposo, M.I.B., Ernesto, M. \& Renne, P.R. 1998. Paleomagnetism and 40Ar/39Ar dating of the early Cretaceous Florianópolis dike swarm. Physics of the Earth and Planetary Interiors, 108-4:275290.

Sun S. S. 1980. Lead isotopic study of young volcanic rocks from midocean ridges, ocean islands and island arcs. Phil. Trans $R$. Soc Lond.. A297:409-445.

Taylor, T.R., Vogel, T.A-, Wilband, J.T. 1980. The composite dikes at Mout Desert Island, Maine: an exemple of coexisting acid and basic magmas. Joun. Geol., 88:433-444

Teixeira L.M. 1997. Génesis - programas para modelamento geoquímico. In: Teixeira L.M. 1997. O complexo Caraiba e a Suite São José do Jacuípe no Cinturão Salvador-Curaçá (Bahia-Brasil): pe- trologia, geoquímica e potencial metalogenético. Tese de doutoramento. IGEO - Universidade Federal da Bahia, Salvador.

Tomazzoli, E.R. \& Pellerin, J.R.G.M. 2001a. Alvéolos e Vales Suspensos: feições erosivas comuns no relevo da Ilha de Santa Catarina. In: IX Simp. Brás. de Geografia Física Aplicada, Recife, PE, Bol. de Resumos, p. 97.

Tomazzoli, E.R. , Mizusaki, A.N.P., Lima, E.F., Félix, A., Figueiredo, A.M.G. 2005. Rochas ácidas associadas ao Enxame de Diques Florianópolis na Ilha do Arvoredo e na Ilha de Santa Catarina (SC): dados geocronológicos preliminaries. In: Simpósio de Vulcanismo e Ambientes Associados, III, Anais, CD, cód. E32. Cabo Frio (RJ).

Wilson M. 1989. Igneous Petrogenesis. Unwin Hyman. London, 466pp.

Winchester, J.A. \& Floyd, P.A. 1977. Geochemical discrimination of different magma series and their differentiation products using immobile elements. Chemical Geology, 20:325-343.

Wright J. B. 1969. A simple alkalinity ratio and its application to questions of non-orogenic granite genesis. Geol. Mag. 106:370-384.

Zanini L.F.P., Branco P.M., Camozzato E., Ramgrab G.E. (orgs). 1997. Programa de Levantamentos Geológicos Básicos do Brasil, Folhas Florianópolis/Lagoa, SG.22-Z-D-V/IV, Estado de Sta. Catarina: escala 1:100.000. Brasília: DNPM/CPRM. 223p.

Manuscrito A-1569 Revisão aceita em 14 de junho de 2006 